\title{
Engelli Sporcuların Objektifinden Spor Deneyimini Görmek: Engelleyici Faktörlerin Sosyo-Ekolojik Model Perspektifinden Analizi
}

\author{
Seeing the Sports Experience Through the Lens of the Athletes with Impairment: \\ Analysis of the Constraints Factors from the Perspective of the Socio-Ecological Model
}

\section{${ }^{1}$ Metin ARGAN \\ ${ }^{2}$ Bülent GÜRBÜZ \\ ${ }^{2}$ Funda KOÇAK \\ ${ }^{1}$ Merve ATICI}

${ }^{1}$ Spor Bilimleri Fakültesi, Spor Yöneticiliği Bölümü, Eskişehir Teknik Üniversitesi

${ }^{2}$ Spor Bilimleri Fakültesi, Spor Yöneticiliği Bölümü, Ankara Üniversitesi

\section{Yazışma Adresi \\ Corresponding Address:}

Doç. Dr. Funda KOÇAK

ORCID No: 0000-0001-5029-3006

Ankara Üniversitesi, Spor Yöneticiliği Bölümü

E-posta: fkocak@ankara.edu.tr

\section{öz}

Bu araştırmanın amacı, bedensel engelli sporcuların spora katıılımlarında karşılaştıkları engellere yönelik deneyimlerini ve bu engelleyici unsurların bireylerin spora katılımlarını nasıl etkilediğini Sosyo-Ekolojik Model (SEM) perspektifinden fotoses yöntemi ile anlamaya çalışmaktır. Yorumlayıcı paradigmanın temel alındığı bu nitel araştırmada katılımcılar amaçlı örnekleme yöntemlerinden ölçüt örnekleme yöntemine göre seçilmiştir. Çalışmada yaşları 20-42 arasında değişen, dördü tekerlekli sandalye atletizm ve yedisi tekerlekli sandalye basketbol olmak üzere 11 bedensel engelli sporcu yer almıştır. Araştırmada hazırlanan yarı yapılandırılmış görüşme formu çerçevesinde yüz yüze ve odak grup görüşmeleri ile fotoğraf verisi olmak üzere üç farklı veri toplama tekniği kullanılmıştır. Verilerin analizinde içerik analizi yönteminden yararlanılmıştır Analiz sonucunda bedensel engelli sporcuların spor deneyimlerini etkileyen kişisel, sosyal, çevresel, kurumsal ve politik faktörler belirlenmiştir. Kişisel engellerin temelde bedensel engell sporcuların tekerlekli sandalye sporlarına uyum sağlama ve engellilik durumlarının yarattığı sorunlardan kaynaklandığı görülmüştür. Sosyal engellerin, prososyal davranış engelleri ve damgalamanın yarattığı toplumsal bakış açısı sebebiyle oluştuğu sonucuna ulaşılmışır. Çalışmada en çok vurgu yapılan çevresel engeller ise spor alanlarına ulaşımda kamusal alanların iyi tasarlanmamasından ve toplumsal yaşamda bireylerin bazı kurallara uymamasından kaynaklanan erişim engelleri üzerine temellenmektedir. Kurumsal engeller temasında spora ilişkin kaynaklara ulaşmada sürdürülebilirliğinin olmayıșı ve sistematik yaklaşımların benimsenmediği görülmüştür Politik engeller temasında ise toplumun engellilere yaklaşımı konusunda yeterince politikalar üretilmediği, medya etkisinin engelliler için yeterince kullanılmadığı belirtilmiştir. Sonuç olarak bedensel engelli sporcuların spora katılım deneyimini etkileyen ve SEM'in beş boyutunu da içeren çok faktörlü engeller bulunmaktadır. Bedensel engelli sporcuların karşılaşıłıları bu engeller günlük hayatlarını etkilediği gibi spor hayatlarını da olumsuz etkilemektedir. Bu engellerin ortadan kalkması veya azaltılması durumunda engelli sporlarının daha fazla gelişim göstereceği düşünülmektedir.

Anahtar Kelimeler: Bedensel engel, Engelli sporcu, Engeller, Sosyo-ekolojik model, Spor

\section{ABSTRACT}

The aim of this study was to understand the experiences of athletes with a physical impairment regarding the constraints they face in their participation in sports and how these constraints affect their participation in sports from the Socio-Ecological Model (SEM) perspective with the photo voice method. In this qualitative study based on the interpretative paradigm, the participants were selected according to the criterion sampling method, which is one of the purposeful sampling methods. Four wheelchair track and field athletes and seven wheelchair basketball athletes with a physical impairment $(n=11)$ aged 20-42 years old included in this study. In the framework of the semi-structured interview form, three different data collection techniques were used in the collection of research data: face-to-face individual interview, focus group interview, and photographic data. Content analysis method was used in the analysis of the data. As a result of the analysis, it was determined that there were personal, social, environmental, institutional and political factors that affect the sports experiences of athletes with a physical impairment. It was found that those personal constraints were mainly caused by the problems of athletes adaptation to wheelchair sports and their impairment. Social constraints were caused by prosocial behavioral barriers and the social perspective created by stigmatization. The most emphasized environmental constraints in the study were based on the access constraints arising from the poor design of public spaces in accessing sports facilities and individuals' failure to comply with certain rules in social life. In the theme of institutional constraints, it was observed that there were no sustainability and systematic approaches in reaching sports-related resources. In the theme of political obstacles, it is stated that there were not enough policies regarding the approach of the society to the individuals with a disability and the media influence were not used sufficiently for the the individuals with a disability. As a result, there are interrelated and multifactorial constraints that affect the sports participation experience of athletes with a physical impairment and include all five dimensions of SEM. These constraints faced by athletes with a physical impairment affect their daily lives as well as their sports life negatively. If these constraints were eliminated or reduced, it was thought that disability sports will develop further Keywords: Physical impairment, Athletes with a disability, Constraints, Socio-ecological model, Sport 


\section{GíRIŞ}

Günümüzde spora katılımın tüm bireyler için sosyal, fiziksel ve psikolojik sağlığın geliştirilmesine yönelik faydalarının bilinmesinin yanında, bu faydaların engelli sporcular için daha önemli bir rol oynadığı görülmektedir. Sporun tüm olumlu etkilerinin yanı sıra engelli sporları bir rehabilatasyon ve sosyalleşme aracı olarak da görülmektedir (Albrecht ve diğ., 2019; Richard ve diğ., 2021). Dünya Sağlık Örgütü ve Dünya Bankası verilerine göre dünya nüfusunun \% 15'i ya da dünyadaki bir milyar civarında bireyin bir tür engellilik durumu ile karşı karşıya olduğu görülmektedir (World Health Organization [WHO] ve World Bank [WB], 2011). Türkiye'de ise engelli sağlık kurulu raporlarını esas alarak oluşturulan Ulusal Engelli Veri Sistemi'ne kayıtlı ve hayatta olan 1.417.202'si erkek, 1.091.074'ü kadın olmak üzere 2.508.276 engelli birey bulunmaktadır. Ancak Türkiye İstatistik Kurumu'nun 2019 yılı Türkiye Sağlık Araştırması verilerine dayandırdığı istatistiklere göre süreğen hastalıklarda dikkate alındığında Türkiye nüfusunun \%15.3’ü engelli bireylerden oluşmaktadır (Türkiye İstatistik Kurumu [TÜi̇], 2019).

Engellilik genellikle fonksiyonel sınırlılıklarla ilişkili olarak görülmektedir ancak Dünya Sağlık Örgütü (2016) engelliliği; bozukluk, etkinlik kısıtlaması ve katılım sınırlamasını kapsayan bir şemsiye kavram olarak görmektedir. Bozukluk, vücut işlevi veya yapısındaki sorunlar; etkinlik kısıtlaması, bir kişinin bir görevi veya eylemi gerçekleştirirken karşılaştı̆ı bir zorluk; katılım sınırlaması ise, bireyin yaşam durumlarına dâhil olurken yaşadığı sorunları kapsamaktadır (World Health Organization [WHO], 2016). Başka bir tanıma göre ise engellilik, "fiziksel, zihinsel, ruhsal ve duyusal yetilerde çeşitli düzeyde kayıplardan dolayı topluma diğer bireyler ile birlikte eşit koşullarda tam ve etkin katılımı kısıtlayan tutum ve çevre koşullarından etkilenme” olarak tanımlanmaktadır (Engelliler Hakkında Kanun, 2005).

Günümüz toplumlarında engelli bireyin çevresinden bağımsız olarak değerlendirilip engelliliğin sadece bedeni ilgilendiren bir durum olarak görüldüğü "tıbbi modelden" ziyade toplum tarafindan engelli olarak görüldüğü bir "sosyal model”e geçiş yapıldığı görülmektedir (Haegele ve Hodge, 2016). Sosyal model kuramcıları daha çok engellilerin çevrelerine odaklanarak, engelli kişilerin günlük yaşamlarında karşılaştıkları engellerin sosyal katılımlarını etkilediğini savunmaktadırlar. Sosyal model yaklaşımlarının merkezinde, çevresel şartların ve sosyal tutumların engellilik durumunun yanında sosyal olarak bir baskı oluşturduğu görüşü bulunmaktadır (Oliver, 2013). Engelliliğe sosyal model yaklaşımları, organizasyonların, yapıların, süreçlerin ve uygulamaların, engelli kişilerin sosyal, politik ve kültürel yaşamlarında gerekli olan katılımı ve desteği sağlayabileceğini vurgulamaktadır. Ancak hem serbest zaman (Singleton ve Darcy, 2013) hem de spor yönetimi (Misener ve Darcy, 2014) alanında yapılan araştırmalarda farklı toplumların belirgin bir şekilde sosyal model anlayışında eksikliklerin olduğu belirtilmektedir. Bu nedenle engelli bireyler sosyal yaşam içerisinde daha fazla engelle karşılaşmaktadırlar.

Karşılaşılan bu engellere ilişkin politika yapıcılar, engellilerin toplumsal hayata etkin olarak katılmasını ve karşılaştıkları engelleri ortadan kaldırmayı hedefleyen çeşitli politikalar üretmektedir. Ülkemizin de taraf olduğu Birleşmiş Milletler Engelli Haklarına İlişkin Sözleşme, dünyada birçok ülkenin vatandaşlarının haklarını kültürel bir yaşama kabul ettirmek için sahip olduğu engellilere yönelik politikaları ve ilgili mevzuatını güçlendirmektedir (Engellilerin Haklarına İlişkin Sözleşme, 2009). Sözleşmenin 30. Maddesi, “... Engellilerin her seviyedeki genel spor etkinliklerine mümkün olduğunca tam katılımını cesaretlendirmek ve artırmak" olarak belirlemiştir. Engellilik insan hakları meselesi olarak görülmektedir (Smith ve Sparkes, 2012). Sözleşmeye taraf olan devletlere, engellilerin spora ve serbest zaman etkinliklerine katılımının artırılması için çeşitli sorumluluklar yüklenmektedir. Bu politika girişimlerine rağmen, engelli bireyler önemli ölçüde ayrımcılık, istisnai olarak daha düşük istihdam seviyeleri ve genel nüfusa oranla önemli ölçüde yoksullukla mücadele etmektedirler (Erdugan, 2010; WHO ve WB, 2011).

http://www.sbd.hacettepe.edu.tr 
Spor ve Rekreasyona Katılım Engelleri ve Engellilik: Dünyadaki pek çok ülkede yapılan araştırmalar engelli bireylerin genel nüfusa oranla spora daha az katılım firsatı elde ettiğini göstermektedir (Chatfield ve Cottingham II, 2017; Hammond ve Jeanes, 2018; Hoekstra ve diğ., 2019; Verdonschot ve diğ., 2009). Türkiye özelinde değerlendirildiğinde ise Gençlik ve Spor Bakanlığı (GSB) verilerine göre 8.360.302 lisanslı sporcu bulunurken engelli sporcu sayısı ise 42.638'dir (Gençlik ve Spor Bakanlığı Stratejik Plan 2019-2013, 2018). Tüm lisanslı sporcuların içerisinde engelli sporcuların oranı ise \% 0.51 civarındadır. Türkiye Bedensel Engelliler Spor Federasyonu 2019 verilerine göre bu oran içerisinde ülkemizde 2202 bedensel engelli sporcu bulunmaktadır. Engelli bireylerin spora yöneliminin bir devlet politikası haline gelmesi ile birlikte son yıllarda ülkemizdeki lisanslı engelli sporcu sayısı da artmıştır. Engelli sporcular, Türkiye Bedensel Engelliler Spor Federasyonu, Türkiye Görme Engelliler Spor Federasyonu, Türkiye İşitme Engelliler Spor Federasyonu, Türkiye Özel Sporcular Spor Federasyonu bünyesinde faaliyet göstermektedirler. Bu sporcuların bir kısmı doğuştan veya erken çocukluk dönemindeki bazı nedenlerden dolayı, diğer bir kısmı ise sonradan gençlik ya da yetişkinlik dönemlerinde özel gereksinimlere ihtiyacı olan bireyler haline gelmişlerdir. Özellikle son yıllarda engelli sporcu sayılarında artış olsa da Türkiye'deki engelli nüfus oranı değerlendirildiğinde, engelli bireylerin spora katılım oranlarının oldukça düşük olduğu görülmektedir.

Engelli bireylerin spora ve fiziksel aktiviye katılımının sosyal, fiziksel ve psikolojik faydalarının varlığı araştırmacılar tarafından sıklıkla ortaya koyulmaktadır (Grenier ve Kearns, 2012; Martin, 2013; Sarol ve Çimen, 2015). Bu faydalara ikinci sağlık sorunu riskini azlatma (Jaarsma ve diğ., 2014a), içsel motivasyon düzeyinde artış (McLoughlin ve diğ.), kişiler arası beceriler ve sosyalleşme düzeyinde artış örnek olarak verilebilir (Hutzler ve diğg., 2013). Spora katılım tüm bireyler için, kişisel, kişilerarası ve yapısal kısıtlamalar arasındaki karmaşık bir etkileşim olarak görülmektedir (Jackson ve Scott 1999). Spora erişim kısıtlanırsa, engellenirse veya reddedilirse, spora dahil olmanın faydaları gerçekleştirilememektedir (Driver ve diğ., 1991; Liu 2009).

Engelli bireylerin spora katılımı ile ilgili literatürün elit spor katılımı ve rekreasyonel katılım olmak üzere iki ana odağı bulunmaktadır (DePauw ve Gavron 2005; Smith ve diğ., 1996). Engelli bireylerin serbest zaman katılımı ile ilgili deneyimlerini inceleyen araştırmalarda açık alan rekreasyonunda algılanan engeller ve faydalar (Burns ve Graefe, 2007; Ghimire ve diğ., 2014), engellik ve destek ihtiyaçlarının spora katılım kısıtlamaları üzerindeki etkisi (Darcy ve diğ., 2017), rekreasyon katılımında başa çıkma stratejilerinin belirlenmesi (Lyu ve Lee, 2016), rekreasyonel etkinliğe katılımın sağladığı faydalar ve terapatik rekreasyon (Mobily ve Dieser, 2018) alanlarında yoğunlaştığı görülmektedir. Engelli bireylerin spora katılımı ile ilgili literatür incelendiğinde ise son dönemlerde yapılan araştırmaların, engelli sporcularda sosyal içerme ve dışlanma (Burns, 2020) motivasyon kaynakları, karşılaşılan engeller ve kolaylaştırıcılar (McLoughlin ve diğ., 2017), engelli sporcuların sosyal değişime katkı sağlamak için bulundukları eylemlerle ilgili olduğu görülmektedir (Haslett ve diğ., 2020).

Spor ve fiziksel aktiviye katılımda engelli bireylerin genellikle çok sayıda engelle karşılaştıkları görülmektedir (Misener ve Darcy, 2014). Misener ve Darcy (2014), bu faktörleri çevresel faktörlerin yarattı̆̆ı engeller (spor tesislerinin erişilebilirliği), ve kişisel faktörler (sosyal demografik hususlar) olarak ifade etmiştir. Buna göre, engelli bireylerin tesislerin yetersizliğinden, ulaşımda gerekli uyarlanmaların yapılmamasından veya erişimin zorluğu nedeniyle (örneğin rampa eğimi, kaldırımlar, engelli asansörü vb.) fiziksel aktiviteye düşük veya hiç katılım göstermedikleri görülmektedir (Kang ve diğ., 2007). Cottingham ve diğ. (2016) ise fiziksel, ekonomik ve psikolojik engellerin altını çizmiştir.

Literatür incelendiğinde, engelli bireylerin; spora nasıl dahil edileceğine dair anlayış ve farkındalık eksikliği, katılım, eğitim ve rekabet için sınırlı fırsatlar ve programlar, erişilebilir tesislerin eksikliği, sınırlı erişilebilir ulaşım ve bilgi ve 
kaynaklara sınırlı erişim gibi pek çok engelle yüz yüze kaldıkları görülmektedir (DePauw ve Gavron, 2005; Misener ve Darcy, 2014). Erişilemeyen fiziksel ortamlar (örneğin, içinde hareket etmek için yeşil alanlara ulaşım eksikiği, tekerlekli sandalye erişimi için çok dar olan spor salonu kapıları ve erişilemeyen banyolar veya soyunma odaları), uygun olmayan ekipmanlar (örneğin, havuz sandalyesi veya koltuğun olmaması), maliyet, "aşırı korumacı" diğerleri, güvenlikle ilgili kişisel kaygılar, kötü hava koşulları, sınırlı sosyal destek, motivasyon eksikliği, istenmeyen ilgiyi çekme kaygısı ve başkalarının engelliliğiyle ilgili olumsuz sosyal tutumlar spor ya da fiziksel aktiviteye katılıma ilişkin diğer engelleyici faktörlerdir (Smith ve Sparkes, 2012). Bedensel engelli sporcular özelinde incelendiğinde ise her ne kadar erişim için hayati öneme sahip olsa da tekerlekli sandalye kullanımından kaynaklı engeller, çevre düzenlemelerinin yetersiz olması, düşme korkusu ve ekipman eksikliği dikkat çekmektedir (Martin, 3013). Sotiriadou ve Wicker (2014) ise serbest zaman engelleri modelini kullanarak bedensel engelli bireylerin fiziksel aktiviteye katılım davranışını incelemişlerdir. Bedensel engelli bireylerin, kişisel, kişilerarası ve yapısal olarak fiziksel aktiviteye katılımda engellerle karşılaştıkları ve engelliliğin türü, kişinin engellilik nedeniyle kısıtlanma derecesi, yaş, cinsiyet ve eğitimin katılım üzerinde önemli bir etkiye sahip olduğunu belirtmişlerdir.

Teorik Çerçeve: Araştırma nitel araştırma yaklaşımında tasarlanmış bir fotoses çalışmasıdır. Yorumlayıcı paradigmanın temel alındığı bu araştırmada, bedensel engelli sporcuların deneyimleri yoluyla elde edilen düşünceler belirli sosyal bağlamlar içinde tartışılarak yorumlanmaya çalışılmaktadır. Bu tür çalışmalar katılımcıların genel bakış açılarına ve hayata yükledikleri anlamlara dayanmaktadır (Malterud, 2016). Araştırmanın kuramsal çerçevesini ise sosyal model kuramlarından Sosyo-ekolojik Model (SEM) oluşturmaktadır.

Bireyin fiziksel özelliği, onun içinde yaşadığı toplumun bir parçası olmasının engelleyicisi değildir, ancak engelliliğe yüklenen anlam ve etiketleme bu durumu oluşturmaktadır. Bireylerin karşılaşığı engeller aynı zamanda ekolojik sistem yaklaşımına vurgu yapmaktadır. Bu yaklaşımda birey; aile, arkadaşlar, sosyal hizmetler, politikalar, inanç sistemi, mal ve hizmet sistemi, çalışma hayatı ve eğitim sistemi başta olmak üzere çevredeki pek çok sistemle dinamik etkileşim içerisinde bulunan bir varlık olarak ele alınmaktadır. Ekolojik sistem yaklaşımı, birey ve diğer sistemler arasındaki karşıllklı etkileşimin tanımlanmasında önemli bir fonksiyona sahiptir (Bronfenbrenner, 1979).

Fiziksel aktivite ve spora katım ile ilgili araştırmalarda çeşitli ekolojk modeller kullanılmaktadır. Ancak davranışsal etki seviyelerini kavramsallaştırmak için spor alanına en uygun olan modelin McLeroy ve diğ. (1988) tarafindan sağlığın gelişimi (health promote) için geliştirilen SEM olduğu görülmektedir. SEM, bireyi çevreleyen çeşitli faktörler arasındaki etkileşimi kabul etmekte ve davranışın beş alt boyutta sınıflandırılan faktörler tarafından etkilendiğini belirtmektedir. Bunlar; kişisel, kişilerarası, kurumsal, çevresel faktörler ve politika kaynaklarıdır. Kişisel faktörler, algılanan işlevsel yetenek, sosyo-ekonomik durum, eğitim seviyesi, istihdam durumu ve motivasyon değişkenleri gibi bireysel özellikleri içermektedir. Sosyal faktörler, kültürel olarak uygun sosyal destek ve kişinin sahip olduğu sosyal ağlarla ilgilidir. Kurumsal faktörler, davranış değiş̧ikliklerini desteklemek için kullanılan örgütsel özelliklerin ve kaynakların rolü olarak değerlendirilmektedir (Fleury ve Lee, 2006). Çevresel faktörler, fiziksel aktiviteye katılımı etkileyen şehirdeki trafik veya toplu taşıma gibi daha geniş değişkenleri içeren fiziksel ortam ile ilgili önemli bir etkiye sahip olan kaynaklarla ilgilidir (Úbeda-Colomer ve diğ., 2019). Politikalar ise, fiziksel aktivite katılımını etkileyen kamu politikalarını kapsamaktadır (Obrusnikova ve Cavalier, 2011).

Engelli sporcuların kendi bakış açılarıyla spora katılımda karşılaştıkları, hissettikleri ya da düşündükleri engeller sınırlı bir biçimde ele alınmış bir konu olmaya devam etmektedir. Literatürde engellilerin karşılaşıs̆ğ engellere ilişkin çok sayıda araştırmaya rastlanmasına karşın (Crawford ve Stodolska, 2007; Darcy ve diğ., 2017; Ives ve diğ., 2019) aktif 
engelli sporcuların fotoses yöntemi kullanılarak karşılaştıkları engelleri betimleyen araştırmalar yok denebilecek kadar azdır. Ülkemizde ise engelli bireylerin fiziksel aktiviteye katılım engelleri ile ilgili bir çalışma yapılmış olsa da (Esatbeyoğlu ve Karahan, 2014) bedensel engelli elit sporcularla yapılmış bir çalışmaya rastlanmamıştır. Bu nitel araştırmanın amacı, bedensel engelli sporcuların spora katılımlarında karşılaştıkları engellere yönelik deneyimlerini ve bu engelleyici unsurların bireylerin spora katılımlarını nasıl etkilediğini SEM bağlamında fotoses yöntemi ile anlamaya çalışmaktır.

\section{YÖNTEM}

Araştırma Modeli: Araştırmaya katılan bedensel engelli sporcular karşılaştıkları engelleri ve toplumsal tutumları nasıl algıladıklarını ve deneyimlerini nitel araştırma yöntemlerinden fotoses yöntemi ile ifade etmişlerdir. Fotoses, gerçekliği belgelemek ve yansıtmak için topluluk temelli katılımcı araştırmalarda kullanılan nitel bir yöntemdir. Fotoses araştırmaları (a) katılımcıların kaynaklarını ve engellerini yakın topluluklarında belgelemelerini ve yansıtmasını sağlamak; (b) fotoğrafları, eleştirel diyalog oluşturmak ve sosyal sorunları çözmek için bilgi üretmek için kullanmak ve (c) değişimi etkileyebilecek ve politika yapıcılara ulaşabilecek bulgular üretmek (Wang ve Burris, 1997) amacıyla yapılmaktadır. İlk kez Wang ve Burris (1994) tarafından uygulanan bu yöntem 'fotoğrafların kısa hikâyesi' olarak tanıtılmıştır. O zamandan itibaren bireylerin veya toplulukların güçlü yönleri veya zayıf yönleri üzerine düşünmelerine olanak sağlayan güçlendirici bir yöntem haline gelmiştir. Katılımcılardan belirlenen bir temaya ilişkin fotoğraf talep edilmesine dayalı bu yöntem, özellikle engelli gruplarda, sağlık alanında ve bazı sosyal alanlarda yaygın olarak tercih edilmektedir (Argan ve diğ., 2020). Araştırma bedensel engelli sporcuların spora katılımda yaşadıkları engellere yönelik deneyimleri üzerinde durulduğundan fenomenoloji deseni tercih edilmiştir. Fenomenolojik çalışmalar kişilerin bir fenomen ya da kavramla ilgili yaşanmış deneyimlerinin ortak anlamlarını tanımlamaya çalışmaktadır (Creswell, 2018).

Katılımcılar: Araştırmaya 4 kadın ve 7 erkek olmak üzere toplam 11 yetişkin (20-42 yaş arası) bedensel engelli sporcu katılmıştır. Katılımcılar amaçlı örnekleme yöntemlerinden ölçüt örnekleme yöntemine göre araştırmaya dâhil edilmişlerdir. Araştırmaya katılan sporcuların 18 yaşından büyük olması, tekerlekli sandalye basketbol ve tekerlikli sandalye atletizm sporcusu olması ve en üst ligde yer almış olması araştırmaya katılma ölçütleri olarak belirlenmiştir. Araştırmaya katılan sporcular, araştırmada kimliklerinin ve fotoğraflarının özellikle yer almasını istediklerini belirtseler de, etik kurallar gereğince katılımcılara kod verilmiştir. Katılımcıların kişisel bilgileri Tablo 1'de özetlenmiştir.

Tablo 1

Katılımcıların Kişisel Bilgileri

\begin{tabular}{lccccc}
\hline Katılımcılar & Cinsiyet & Yaş & Engellilik Türü & Ĕgitim & Spor Branşı \\
\hline Leyla & Kadın & 27 & Ortopedik Engelli & Lise & TSA \\
Ayça & Kadın & 26 & Çift Bacak Ampute & Lise & TSA \\
Zehra & Kadın & 25 & Spina Bfida & Üniversite & TSA \\
Neslihan & Kadın & 20 & Spina Bfida & Lise & TSA \\
Ahmet & Erkek & 42 & Ortopedik Engelli & Lise & TSB \\
Ziya & Erkek & 26 & Çift Bacak Ampute & Orta Okul & TSB \\
Yücel & Erkek & 34 & Paraplejik Engelli & Üniversite & TSB \\
Hasan & Erkek & 33 & Sol Dizüstü Ampute & Üniversite & TSB \\
Remzi & Erkek & 28 & Sol Dizaltı Ampute & Lise & TSB \\
Can & Erkek & 35 & Paraplejik Engelli & Lise & TSB \\
Emre & Erkek & 39 & Ortopedik Engelli & Lise & TSB \\
\hline
\end{tabular}

TSB: Tekerlekli Sandalye Basketbol, TSA: Tekerlekli Sandalye Atletizm

Prosedür: Araştırmada veri üretimi iki aşamadan oluşmaktadır. Veri üretiminin ilk aşamasını katılımcılar tarafından oluşturulan fotoses dosyaları ikinci aşamasını ise, odak grup görüşmeleri ve yüz yüze bireysel görüşmeler oluşturmaktadır. Bu aşamalar katılımcıları araştırma sürecine dâhil etmek için etkili bir yöntem olarak tercih edilmiştir. 
Araştırma öncesinde görüşmeler ile katılımcılara fotoses çalışması hakkında bilgilendirme yapılmıştır. Verilere; görüşme, fotoses, ses/görüntü kaydı ve odak grupları dâhil olmak üzere birden fazla veri toplama yönteminin kombinasyonu sonucunda ulaşılmıştır. Araştırma iki aşamada gerçekleştirilmiştir.

Aşama 1: Katılımcılardan spora katılımlarında engelleyici faktör olarak gördükleri unsurların (yer, nesne, kişi vb.) fotoğrafını çekmeleri veya temsili fotoğrafları seçmeleri istenmiş ve kendilerine iki ay civarında süre verilmiş̧ir. Daha sonra bu fotograflara yükledikleri anlamları açıklamaları istenmiştir. Katılımcıların çekebileceği fotoğraf sayısına herhangi bir sınırlama getirilmemiştir. Katılımcılar çektikleri/seçtikleri fotoğraflarla spora katılımlarında karşılaştıkları engelleyici unsurları belirlemişlerdir.

Aşama 2: Veri üretiminin ikinci aşamasında, fotograf verisi toplamanın sonunda katılımcıların fotoğraflarını ve deneyimlerini tartışmak üzere her katılımcı ile bir yüz yüze bireysel görüşme ve toplamda da iki adet odak grup görüşmesi yapılmıştır. Yüz yüze görüşmeler katılımcılara bakış açılarını ve deneyimlerini daha iyi yansıtmalarını sağlayacak bir firsat yaratmaktadır (Patton, 2002). Odak grup görüşmelerinde ise yüz yüze görüşmeye ek olarak katılımcılar aynı durumu yaşayan katılımcılarla paylaşımda bulunarak, yeni verilerin üretilmesine katkı sağlamaktadırlar. Katılımcıların sayısı konusunda kesin yargı bulunmamasına rağmen odak grupların 4-12 kişiden oluşması önerilmektedir (Çokluk ve diğ., 2011). Çalışma kapsamında birincisi 5 katılımcı ile, ikincisi 6 katılımcı ile olmak üzere iki odak grup görüşmesi gerçekleştirilmiştir. Katılımcılardan, spora katılımlarında engel unsuru olarak gördükleri durumlara ilişkin çektikleri/temsili olarak seçtikleri fotoğraflar arasından bakış açılarını en iyi yansıtan fotografları seçmeleri istenmiş̧ir. Bedensel engelli sporcular kendilerini spora katılımda en çok engellediğini düşündükleri 4-5 adet fotoğraf olmak üzere toplam 51 adet fotoğraf seçmişlerdir. Yüz yüze bireysel görüşmeler ve odak grup görüşmeleri, katılımcıların kendi deneyimlerini paylaşmaya teşvik edildiği, açık uçlu soruların olduğu ve yarı yapilandırılmış görüşme formatında ve çevrimiçi olarak gerçekleştirilmiştir. Yarı yapılandırılmış görüşme soruları SEM çerçevesinde oluşturulmuştur. (Örn: Günlük yaşamınızda en çok hangi güçlüklerle karşılaşıyorsunuz?, Spora katılımda en çok hangi zorlukları yaşıorsunuz?, Spora katılımda karşılaşıı̆ıınız zorlukları nasıl aşmaya çalışıyorsunuz?). Her odak grup görüşmesi ortalama 30 dakika sürmüştür. Yüz yüze bireysel görüşmeler ortalama 15-20 dakika civarında sürmüştür. Görüşmelere başlamadan önce ses kayıt cihazı kullanımı için katılımcılardan izin alınmıştır. Araştırmanın etik açıdan uygunluğu Eskişehir Teknik Üniversitesi Sosyal ve Beşerî Bilimler Bilimsel Araştırma ve Yayın Etiği Kurulu tarafından gözden geçirilmiş ve onaylanmıştır. Aydınlatılmış onam formu ile katılımcılardan izin alınarak, araştırmaya gönüllü olarak katılmaları sağlanmıştır.

Verilerin Analizi: Görüşmeler sonucu elde edilen veriler içerik analizi yöntemi ile analiz edilmiştir (Patton, 2002). Verilerin analizinde öncelikle ses kayıtları bilgisayar ortamına aktarılarak deşifre işlemi gerçekleştirilmiş ve verilere aşinalık kazanılmıştır. Ayrıca sporcular tarafından seçilen/çekilen fotoğraflar ilk önce hikâyeleri ile birlikte ele alınarak engel unsurlarının ne olduğu tespit edilmiştir. Birbiri ile ilişkili olan katılımeı hikâyeleri ve fotoğraf verileri gruplandırılarılmıştır. Daha sonra araştırmanın amacı doğrultusunda kodlamalar yapılmış ve SEM'e uygun olarak temalar belirlenmiştir. Temaları tanımlamak için veri analizi süreci boyunca katılımcılarla iletişsim halinde kalınmıştır.

Araştırmanın İnandırıcılı, Aktarılabilirlik, Güvenilebilirlik ve Doğrulanabilirlik Stratejileri: Nitel araştırmalarda elde edilen bulguların inandırıcılığını sağlamaya yönelik çeşitli stratejiler kullanılmaktadır (Noble ve Smith, 2015). Bu amaçla araştırmada güvenirliğin sağlanabilmesi için, görüşmelerin kayıt altına alınarak, bunların yazıya aktarılması, farklı araştırmacılar tarafından bireysel kodlama yapılması stratejileri kullanılmıştır. Araştırmada geçerliği sağlamak amacıyla Lincoln ve Guba (1986) tarafından önerilerin inandırıcılık, aktarılabilirlik, güvenilebilirlik ve doğrulanabilirlik kriterleri temel alınmıştır. İnandırıcılığın sağlanabilmesi için araştırmada kullanılan veriler çoklu veri 
kaynaklarından toplanarak, veri çeşitlemesi ve verilerin analizinde kodlayıcı çeşitlemesi yöntemleri kullanılmıştır. Aktarılabilirliğin sağlanabilmesi için, elde edilen verilerin sunumunda farklı katılımcıların düşüncelerine yönelik çok sesli alıntılara bulgularda yer verilmiştir. Güvenilebilirlik için, analiz sürecinde araştırmanın yazarları ile yürütülen tartışma toplantıları gerçekleştirilmiştir. Son kriter olan doğrulanabilirlik ise, katılımcıların deneyim ve düşüncelerini daha iyi yansıtabilmek amacıyla, araştırmadaki tüm aşamaların ayrıntılı olarak açıklanması ve katılımcıların fotoğrafları kendi cümleri ile hikayeleştirmesiyle sağlanmıştır.

\section{BULGULAR}

Araştırmada SEM'in kişisel, sosyal, kültürel, çevresel ve politik alt boyutları kapsamında bedensel engelli sporcuların spor deneyimlerinde karşıllaştıkları engellere değinilmiştir. Araştırma kapsamında 5 tema için 21 kod oluşturulmuştur. Tablo 2'de SEM perspektifinden ortaya çıkan tema ve kodlar verilmiştir.

\section{Tablo 2}

SEM Perspektifinden Ortaya Çıkan Tema ve Kodlar

\section{SEM Perspektifinden Ortaya Çıkan Tema ve Kodlar}

\begin{tabular}{|c|c|}
\hline $\begin{array}{l}\text { Temalar } \\
\end{array}$ & Kodlar \\
\hline $\begin{array}{l}\text { Engel 1: Kişisel Engeller: Diğerleri Gibi Ama } \\
\text { Diğerlerinden Farkl1 }\end{array}$ & $\begin{array}{ll}\text { - } & \text { bireyin engellilik derecesi } \\
\text { - } & \text { uyum sağlamada güçlük } \\
\text { - } & \text { enerji ve motivasyon eksikliği } \\
\text { - } & \text { maddi durum } \\
\end{array}$ \\
\hline $\begin{array}{l}\text { Engel 2: Sosyal Engeller: Görünür Olma Çabası ve } \\
\text { Görünmezlik Algıs1 }\end{array}$ & $\begin{array}{ll}\text { - } & \text { geride kalanlar } \\
\text { - } & \text { yarım insan } \\
\text { - } & \text { bakışların getirdiği zorluk } \\
\text { - } & \text { negatif damgalama } \\
\text { - } & \text { diğer bireylerin bilgi eksikliği } \\
\text { - } & \text { prososyal davranış engelleri } \\
\end{array}$ \\
\hline $\begin{array}{l}\text { Engel 3: Çevresel Engeller: Tek Beden (Yap1) } \\
\text { Herkese Uymaz }\end{array}$ & $\begin{array}{ll}\text { - } & \text { ulaşım güçlükleri, } \\
\text { - } & \text { erişim engelleri } \\
\text { - } & \text { güvensiz ortamlar } \\
\text { - } & \text { hava koşulları } \\
\text { - } & \text { tasarım eksiklikleri } \\
\end{array}$ \\
\hline $\begin{array}{l}\text { Engel 4: Kurumsal Engeller: Kalıcı Çözümler için } \\
\text { Geride Kalanlar }\end{array}$ & $\begin{array}{ll}\text { - } & \text { sürdürülebilirlik eksikliği } \\
\text { - } & \text { sistematik yaklaşım eksikliği } \\
\text { - } & \text { bağımsızlık temelli ulaşım planlamasının } \\
& \text { yetersizliği }\end{array}$ \\
\hline $\begin{array}{l}\text { Engel 5: Politik Engeller: Spor kapsayıcı mı dışlayıcı } \\
m \imath \text { ? }\end{array}$ & $\begin{array}{l}\text { - } \text { eğitim eksikliği } \\
\text { - } \text { medya etkisi } \\
\text { - } \quad \text { beklentinin karşılanmaması }\end{array}$ \\
\hline
\end{tabular}

Kişisel Engeller: Diğerleri Gibi Ama Diğerlerinden Farklı: Bu tema kapsamında bedensel engelli sporcuların spora katılımındaki kişisel engellerine vurgu yapılmıştır. Kişisel engeller kapsamında bireyin engellilik derecesi, uyum sağlamada güçlük, enerji ve motivasyon eksikliği, maddi durum, bilgi eksikliği kodlarına ulaşılmıştır. Araştırmada sporcuların değindikleri kişisel engeller az sayıda olmuştur. Kişisel engellerle ilgili daha çok yaptıkları spora uyum sağlama sürecinde engellerle karşılaştıkları görülmektedir. Bu konuda bedensel engelli sporcular deneyimlerini şu şekilde ifade etmişlerdir. 
Şekil 1

Kullanilan Materyallerin Birey Üzerindeki Etkisi

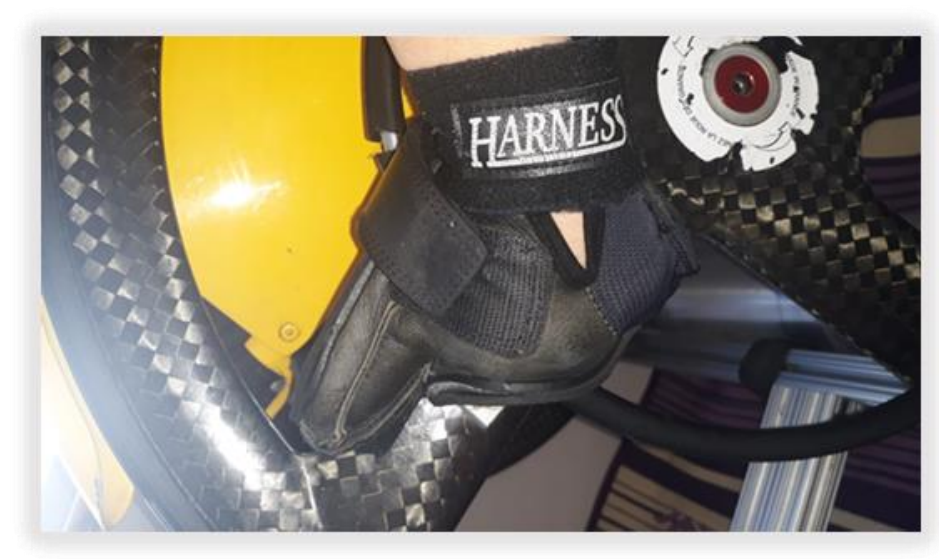

"Benim önümdeki en büyük engellerden biri de kullandığımı malzemelerin hem pahalı hem de alışlması zor olamaslyd. Örneğin eldivenlerim. Spora başlarken en zorlandığım konulardan birisi de eldivenler oldu. Onlara alışana kadar ellerim uyuştu, su topladl yaralar oluştu bu durum beni engelledi ama zamanla eldivenlere de alıştım." (Zehra, yaş 25)

Fotoğraflar sayesinde bedensel engelli sporcular kendilerini daha iyi ifade ettiklerini belirtmişlerdir Kişisel engeller kapsamında yine aynı şekilde Neslihan (yaş, 20) spora katılımında engel olarak gördüğü beslenme probleminden bahsetmiştir.

"Benim en çok zorlandığım konulardan birisi engelim nedeniyle yemek konusuydu. Spora başlamadan önce iştahsız biriydim. Yemek yemeyi fazla istemezdim ancak, spora başladıktan sonra ağır antrenmanlar yaptığımdan dolayı kaybettiğim enerjiyi yerine koymak için canım yemek istemediği halde sporum için yemek yemek zorunda kallyorum." (Neslihan, yaş 20)

Katılımcıların hayat hikayelerinin farklı olmasının yanı sıra spora katılımlarında karşılaştıklarını engeller de oldukça farklılık göstermektedir. Aynı takımda olan ve aynı branşı sergileyen bedensel engelli sporcuların bile, bireysel farklılıklarından dolayı çok farklı engelleyici faktörle karşı karşıya kalabildikleri görülmektedir. Her bireyin hayata ve spora bakış açısı farklılık göstermektedir.

Sosyal Engeller: Görünür Olma Çabası ve Görünmezlik Algısı: Bu tema kapsamında görünmezlik algısı, yarım insan, bakışların getirdiği zorluk, negatif damgalama, diğer bireylerin bilgi eksikliği ve prososyal davranış engelleri kodları oluşturulmuştur. Araştırmada katılımcıların en fazla fotoğraf çektiği/seçtiği ikinci önemli faktör sosyal engeller olarak karşımıza çıkmaktadır. Bedensel engelli sporcular spora katılımla kendilerini daha iyi hissettiklerini, yaşam kalitelerinin arttığını belirterek, yapmış oldukları spor ve elde etikleri başarılar ile toplum tarafından kabul görüldüklerini vurgulamışlardır. Ancak toplumdaki bireylerin onları yok saymalarından dolayı özellikle antrenman ortamlarına erişim sağlamada çok fazla engelle karşılaşıklarını belirtmektedirler. Buna ilişsin olarak Zehra (yaş, 25) bu fotoğrafı çekmiş ve şu ifadeleri kullanmıştır: 


\section{Şekil 2}

Görünür Bir İşaret Olan Görünmezlik Alglsı (Geride Kalanlar)

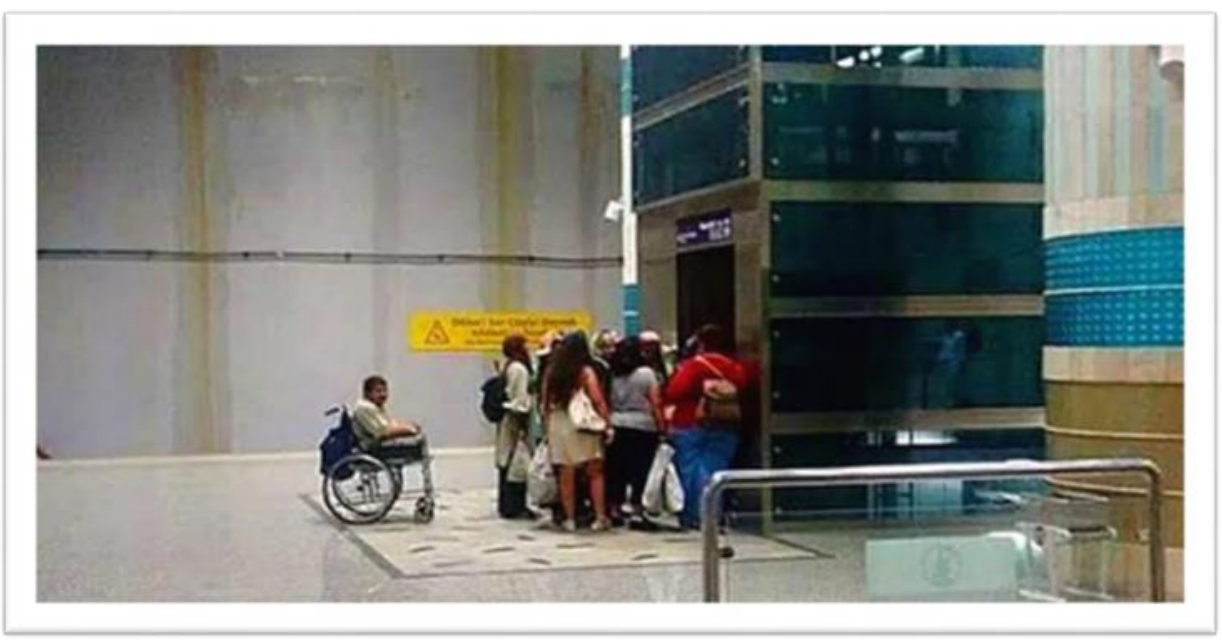

"Antrenmana giderken genelde servis kullaniyorum. Bazen servis olmadiğı zaman toplu taşıma araçlarını kullanıyorum. Özellikle metroyu kullandığım zamanlar genellikle asansörlerin önü dolu oluyor ve onlar beni değil de ben onları beklemek zorunda kaliyorum." (Zehra, yaş 25)

Sosyal engellerin engelli bireyleri daha fazla etkilemesinin bir başka nedeni de bireyin dış faktörlerin etkisinde olmasıdır. Yapılan odak grup görüşmelerinde, engelli bireylerin spora katılımlarının desteklenmesi için, uygulanan spor politikaları, tesislerin uyarlanmışlık düzeyleri, spor yöneticileri, takım arkadaşları ve spora bakış açısının oldukça önemli olduğu belirtilmiştir. Engelli bireylerin spora ilgisinin olmasının yanı sıra, sosyalleşmesi ve kendisini iyi hissetmesi gerekmektedir. Günlük yaşam içerisinde toplumdaki bireylerin engelli bireylere davranış şekilleri katılımcıların spor hayatlarını da doğrudan etkilemektedir. Bu durum ile ilişkili olarak Ahmet (yaş, 42) şu ifadeleri kullanmaktadır:

\section{Şekil 3}

Bakışların Getirdiği Zorluk

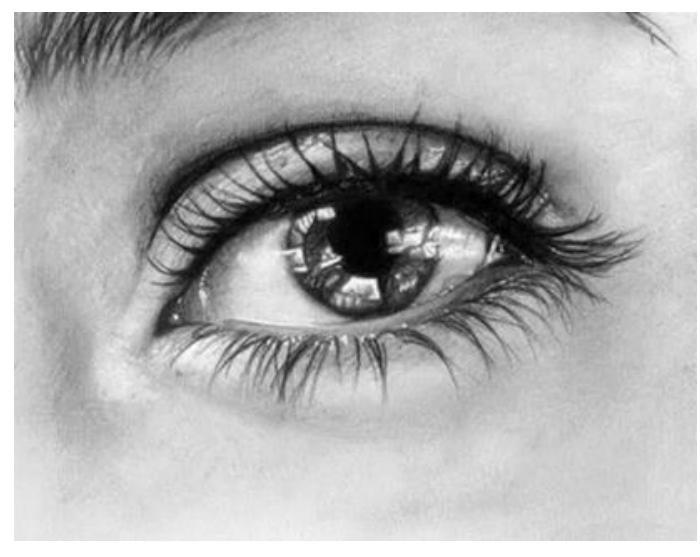

"Şimdi benim için en önemli noktaya geleceğim o da insanların bize bakışları. Dışarıdan bize bakan gözler bizim bu başarılarımıza daima anormal gözle bakar ve bizi yarım insan olarak adlandırtrlar. Bu beni en rahatsı eden olaydır. Çünkü biz eğer güzel bir evde oturuyorsak, güzel bir arabamız varsa ya da güzel bir hayat yaşlyorsak insanlar bunlar nereden geldi bunlara nasıl sahip oldular sorularını sorarlar ama bu soruları kendilerine hiç sormazlar. Ben çok 
zorluklar çektim ama bakışlardan çektiğim zorluğu hiçbir şeyden çekmedim. Ne olursa olsun bir engelli birey olarak çalışmaya ve üretmeye devam eden vatan için hizmet eden bir birey olacağım." (Ahmet, yaş 42)

Bireylerin empati ve merak duygusundan yola çıkarak engelli bireylere çok fazla soru sormalarının da önemli bir prososyal davranış engeli olduğu tespit edilmiştir. Toplum tarafından dışlanan, kabul görmediklerini hisseden bedensel engelli sporcular daha çok olumsuz etkilenerek günlük yaşamlarında bile toplum ile kaynaşmayıp kendilerini soyutladıklarını belirtmiş̧lerdir. Bu durum sosyal engellerin azaltılması ya da ortadan kalkması durumunda engelli bireylerin daha fazla spor ortamı içerisinde olabileceklerini göstermektedir. Bireyin yaşam deneyimleri aynı zamanda onun sosyal çevre içerisindeki davranışlarına da şekil vermektedir. Davranışlar genellikle bireyin sosyal çevre içerisinde yer alan diğer sistemlerle olan etkileşimleri sonucunda meydana gelse de bazı davranışlar kişinin kendi içsel yapısı ve yaşantılarının birer ürünüdür. Sosyal engellerle ilgili seçilen/çekilen fotoğraflar incelendiğinde bedensel engelli sporcuların, diğer engelli sporcular ya da kendi spor alanları ile ilgili herhangi bir engelden bahsetmedikleri dikkat çekmektedir. Bu konuda belirtilen engellerin toplumdaki normal gelişim gösteren bireylerin bilgi eksikliğinden kaynaklandığı görülmektedir. Buna bağlı olarak Ziya (yaş, 26) şu ifadeleri kullanmaktadır:

\section{Şekil 4}

Engelimiz Spora Engel Değil

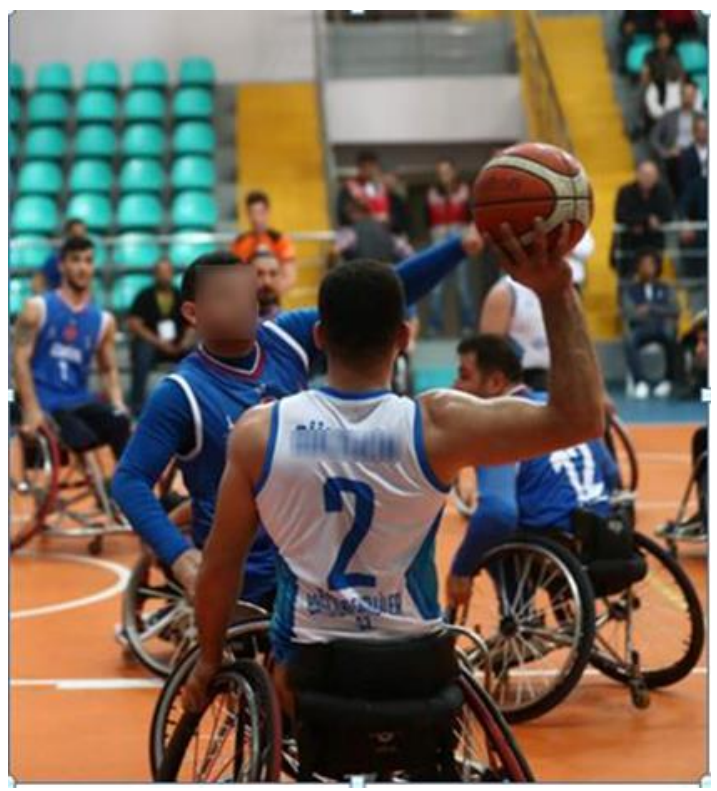

“Insanların bize bakarak imrenmeleri beni rahatsız ediyor. Özellikle şu söylemleri 'Ya helal olsun size iki bacağln yok ya da tekerlekli sandalyedesin ama çok mutlusun pes etmemişsin. Nice insanlar var hayattan bıkmış saçma şeyler yapıyorlar ama size helal olsun...' gibi cümleler. Profesyonel tekerlekli sandalye basketbol oyuncusuyum. Maçlarımıza geliyorlar ya da televizyondan izliyorlar. Vay be engelliler spor yapıyor diyorlar. Bizim yaptığımız spor dünya çapında bir spor, şampiyonlar ligi, UEFA kupası gibi turnuvaları var. Bu durumun varliğını ve bizi daha fazla benimsemeliler çünkü engellerimizin oluşu spor yapmamıza engel değil."(Ziya, yaş 26)

"Her engelliyi dilenci sanmayın lütfen... Antrenmana giderken otobüs duraklarl, ATM'lerin önü, bankaların önü, marketlerde, alışveriş merkezlerinde, kafelerde, arkadaşlarımı veya aileme beklerken kısacası her yerde ve her zaman karşılaş̧tı̆ım durum bu çok ama çok rahatsız oluyorum. Sirf böyle bir durum yaşamamak için kafam her zaman yerde, göz teması kurmaktan kaçıyorum telefonla veya sadece bir yere odaklanarak bekliyorum." (Ziya, yaş 26)

Ayrıca bireylerin diğerleri için çaba harcaması, başkalarının iyiliğini düşünerek yararlı olma amacıyla hareket etmesi, etrafındaki grubun, örgütün ya da çalışanların, refahını sağlamak amacıyla sergilediği davranışlar, olumlu sosyal 
davranışlar olarak değerlendirmektedir. Yardım gerektiren durumlarda olaya tanık olan bireylerin sayısı kişinin yardım etme isteğine etki etmektedir. Herhangi bir olaya tanık olan bireylerin sayısı azaldıkça, bireylerin algıladıkları kişisel sorumlulukları artacağından, yardım verme ihtimali de artacaktır. Bu durumun araştırmaya katılan özel gereksinimli bireylerin çok sık karşılaştığı ve önemli bir engelleyici unsur olduğu tespit edilmiştir. Bu durumla ilgili olarak Ziya (yaş, 26) şu ifadeleri kullanmıştır:

“Çok yardımsever olmayalım lütfen yardım edelim derken beni ve diğer engelli kardeşlerimi çok ama çok sıkıyorlar. Ben çift ampute olan biriyim tek protez kullanıyorum. Yerin ıslak olması ya da bastonumu fazla açmamdan dolayı bazen yere düşüyorum ve yardım edilerek yerden kalkamıyorum. Yardım etmek isteyen kardeşlerime, abilerime ısrarla beni bırakın ben kendim kalkayım dememe rağmen ısrarla kaldırmaya çalışıyorlar. Bende yardım istemediğimi tekrarladıkça yerde kalma sürem uzuyor maalesef bunu ailemde annem de yapıyor. ",

Yukarıda bahsedilen durumlar nedeniyle bedensel engelli sporcular toplum tarafından yeterince kabul görmediklerini düşündüklerinde kişiler arası ilişkilerinde daha hasas olabilmektedirler. Bu nedenle sosyal engellerin azaltılması ya da ortadan kalkması durumunda engelli bireylerin kendilerini daha iyi hissetmeleri sağlanabilir.

Çevresel Engeller: Tek Beden (Yapı) Herkese Uymaz: Bedensel engelli sporcuların spora katılımındaki diğer önemli faktör ise çevresel engellerdir. Araştırmamızda ulaşım güçlükleri, erişim engelleri (örneğin; rampa eğimi, kaldırımlar vb.), güvensiz ortamlar, hava koşulları, tasarım eksiklikleri kodları oluşturulmuştur. Araştırmamızda seçilen/çekilen fotoğraflar incelendiğinde en fazla engelin çevresel engeller olduğu dikkat çekmektedir. Bedensel engelli sporcular spor salonlarının ve diğer kamusal alanların normal gelişim gösteren bireylere göre düzenlendiğini ancak, engellilere yönelik son dönemlerde düzenlemeler yapılsa da yine çok fazla eksikliğin olduğu belirtilmiştir. Katılımcılardan Ayça’ya (yaş, 26) ait resim ve hikâyesi şu şekildir.

“Beni bu tür rampalar üzüyor çünkü çıkamıyorum, yardım istemek zorunda kalıyorum. Bazen insanlar yardım bile etmiyor. Bu yüzden bir yere giderken bana uygun mu değil mi diye önceden araştırıyorum. " (Ayça, yaş 26)

\section{Şekil 5}

Yüksek Ökçeler

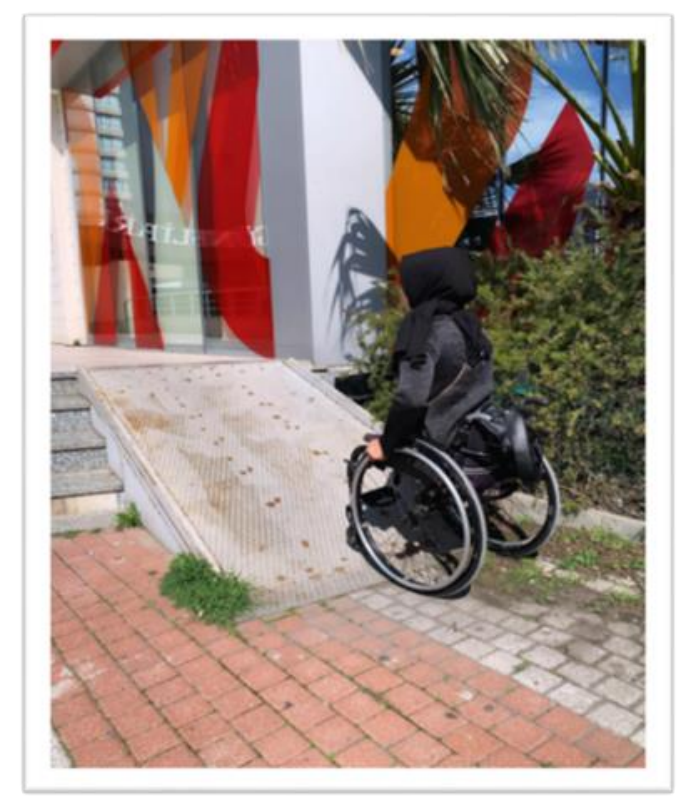

Çevresel faktörlerler bedensel engelli bireylerin spora katılımında oldukça önemli bir faktör olarak görülmektedir. Özellikle kaldırımların yüksekliği, kaldırımlara park eden arabaların varlığg ve engelliler için yapılmış olsa bile engelli 
rampalarının engellilerin kullanımına uygun olmaması araştırmaya katılan bedensel engelli sporcuların ortak sorunu olarak ortaya çıkmaktadır. Bu konuda sporcular görüşlerini şu şekilde ifade etmişlerdir.

"En büyük problemim engelli rampaları ve rampaların önüne park edilmiş araçlar. Bir rampadan kaldırıma çıkıp diğerinden araçlar park ettiği için inememek." (Zehra, yaş 25)

"Şu kaldırımlar bizim için çok büyük bir engel çünkü nasıl çıkacağımızı bilmiyoruz. Bir yere gitmek istediğimizde rampa olmadan gidemiyoruz. Yoldan gitmek istesek araçlardan dolayı daha da tehlikeli bir durumda kalyyoruz." (Neslihan, yaş 20)

"En çok zorlandığımız konulardan birisi de yapılmak için yapılmış hiç bir ise yaramayan rampalar. Bu rampalardan tek başımıza çıkmayı bırakın yârdim alarak bile çıkamıyoruz." (Zehra, yaş 25)

"Benim için en büyük engellerden biri de Arnavut kaldırımlar. Tekerlekli sandalyemin ön tekerleri taknlyyor ve birçok kez de düşüm." (Leyla, yaş 27)

Sporculara göre engelli bireylerin önlerindeki kişisel ve sosyal engellerin tümü ortadan kaldırılsa bile çevresel engellerin varlığı spora katılım oranlarını etkilemektedir. Bu duruma bir de toplumdaki diğer bireylerin davranışları eklendiğinde çevrenin onlar için güvenli olmadığını düşünmektedirler. Buna bağlı olarak (Zehra, 25) bu resmi çekerek hikâyesini şu şekilde ifade etmiştir:

Şekil 6

Güvende Hissetme Arzusu

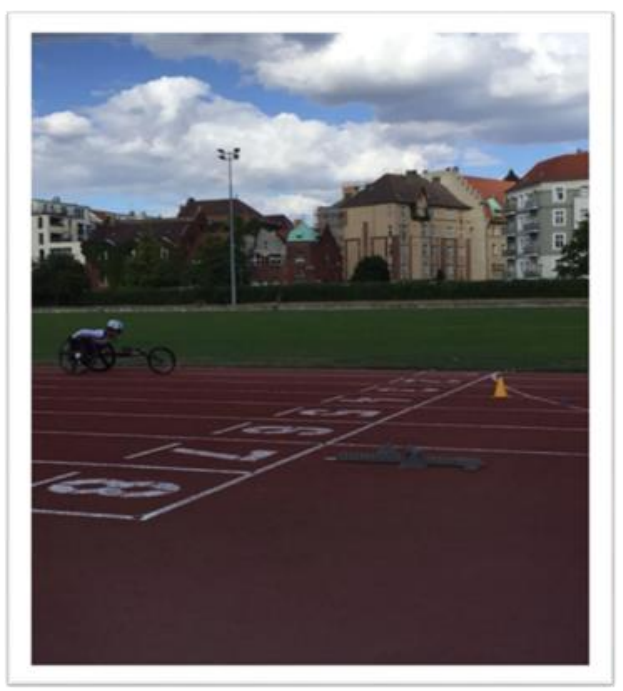

"Antrenmanlarımda beni en zorlayan konu sahaların kalabalıklığıdır. Bu fotograftaki boş sahaları hayal ediyorum. Aniden önümüzden birilerinin geçmesi bizleri zorluyor. Bizim eski sahamı yıkıldı orası sakindi ama yıklldıktan sonra üst taraftaki sahaya geçtiğimizde okuldan gelen küçük yaştaki çocuklar aniden önümüze geçiyorlar. Ani fren yapmak zorunda kallyoruz bu durum hem bizim hem de onlar için çok tehlikeli olabiliyor." (Zehra, yaş 25)

Araştırmaya katılan sporcular tekerlekli sandalye kullandıkları için özellikle çevresel engellerde hava koşullarına dikkat çekmişlerdir. Yağışlı ya da karlı havaların tüm bireyler için zorluklarının olduğunu ancak, bedensel engelli sporcular için daha önemli olduğunu belirtmişlerdir. Bu konuda Neslihan, (yaş, 20) ve Leyla (yaş, 27) tarafindan çekilen fotoğraflar ve hikâyeleri şu şekildedir. 


\section{Şekil 7}

Hareket Etme Zorunluluğu

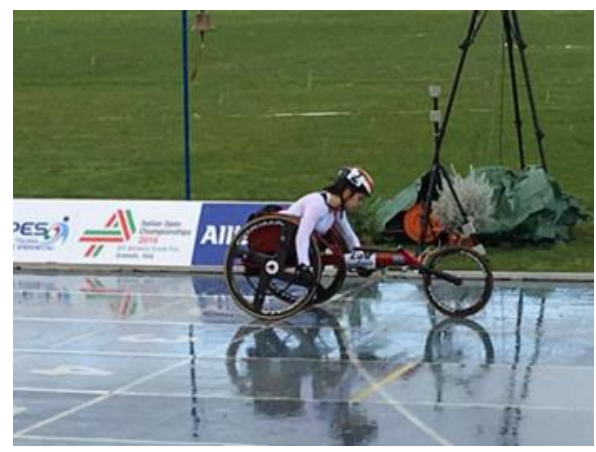

"En önemli engelleyici unsurlardan biri bence hava durumu çünkü bizim spor branşımızda yağmur çok zorlayan bir etken yağmur yağdığında eldivenlerimiz kayganlaştığı için tekerlekli sandalyelerimizi hareket ettirmem daha da zorlaşıyor." (Neslihan, yaş 20)

\section{Şekil 8}

Kontrol Güçlüğ̈̈

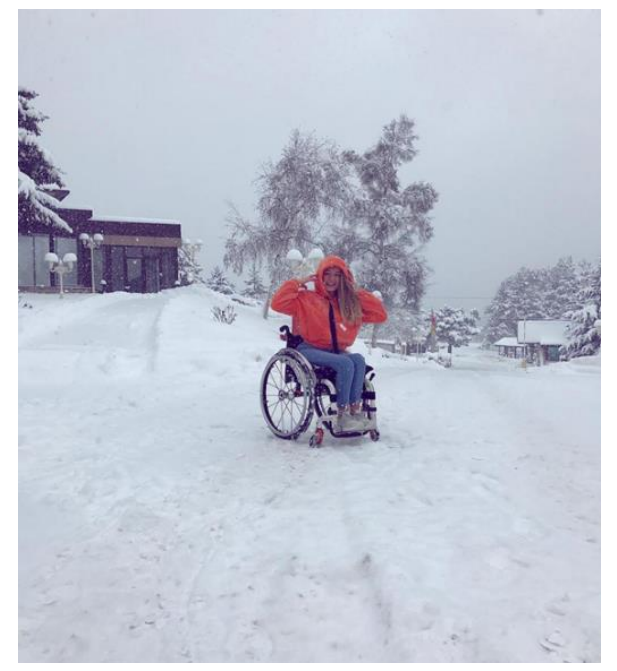

Hava şartları. Çünkü hava şartları bizim için çok büyük bir engel. Özellikle yağmur, kar ve rüzgârda, biz bu şartlarda hem kendimizi hem de sandalyemizi kontrol edemeyebiliriz. Güvenle sandalyelerimizi kullanamaylz.... (Leyla, yaş 27)

Bedensel engelli sporcular antrenmanlar için spor salonlarının yanı sıra sıklıkla park alanlarını kullandıklarını belirtmişlerdir. Ancak pek çok parkın engellilerin ihtiyaçlarını gözeterek tasarlanmadığını düşünmektedirler. Bu konuda Hasan (yaş, 33) tarafindan çekilen fotoğraf ve görüşleri şu şekildedir. 


\section{Şekil 9}

\section{Bize Uyarlanmamıs Parklar}

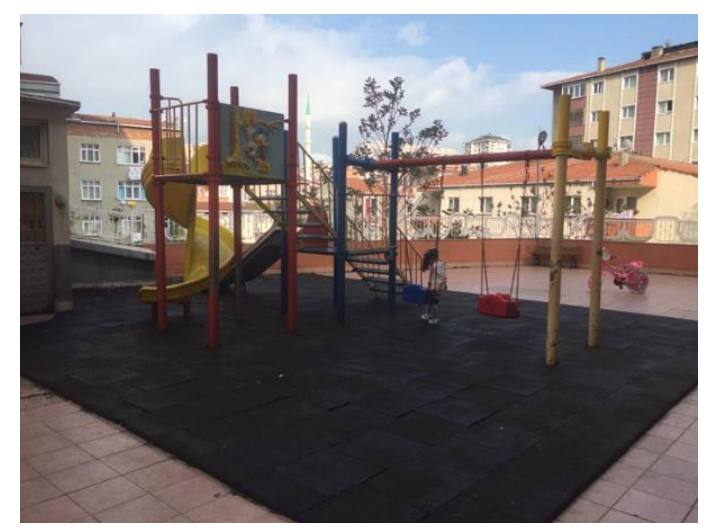

Eski parkların yerine daha modern ve engellilere uygun parkların inşa edilmesi gerekmektedir. Engellilerin parklarda kimseye muhtaç duruma düşmeden spor yapabilmeleri için bir bölüm ayırmaları biz engelli sporcuların daha özgür bir şekilde spor yapmasina yardımcı olacaktır. (Hasan, yaş 33)

Sporcuların görüşlerine göre çevresel engellerin varlığı spora katılımı doğrudan etkilemektedir. Ancak çevresel engellerin pek çoğu (hava koşulları dışında) onlara göre engelli bireyleri göz ardı etmekten ve engelli bireyler hakkında yeterince bilgi sahibi olmamaktan kaynaklanmaktadır. Bu nedenle sosyal engelleri aştıklarında çevresel engelleri de aşabileceklerini düşünmektedirler.

Kurumsal Engeller: Kalıcı Çözümler için Geride Kalanlar: Bedensel engelli sporcuların spora katılımda karşılaştıkları diğer önemli faktör ise kurumsal engellerdir. Kurumsal faktörlerde bedensel engelli sporcuların spor yaptıkları kurumlarlar ya da ortamlarla ilgili karşılaştıkları engeller ortaya koyulmaya çalışılmıştır. Araştırmada katılımcıların en az fotoğraf çektiği/seçtiği üçüncü faktör kurumsal engeller olarak belirlenmiştir. Bu tema kapsamında sürdürülebilirlik eksikliği, sistematik yaklaşım eksikliği ve bağımsızlık temelli ulaşım planlamasının yetersizliği kodları oluşturulmuştur. Bu faktörde bedensel engelli sporcular nitelikli spor ekipmanlarına kurumsal yapıda sistematik olarak ulaşamadıklarını belirtmektedirler. Ayrıca bedensel engelli sporcular tarafından ifade edilen bir diğer kurumsal engel ise, iyi gelişmeler yaşansa da ulaşım sorunun tüm engelli sporcular ve kulüpler için ilgili kurumlar tarafindan sürdürülebilir olarak çözülememesidir. Kendi tekerlekli sandalyesini ve takım otobüsü fotoğrafı seçmeyi tercih eden Remzi (yaş, 28) görüşlerini şu şekilde belirtmiştir.

Şekil 10

Erişmek Hiç Kolay Değil

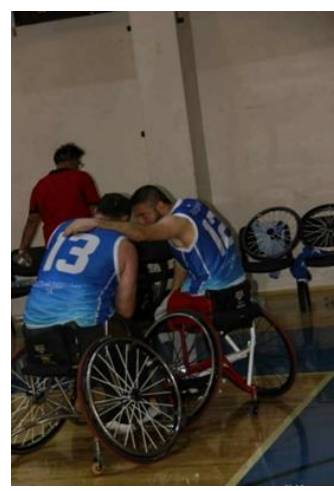


“... Bizim en büyük engelimiz ĕger tekerlekli sandalye de basketbol oynamak istiyorsanız özel yapım spor sandalyelerinizin olması gerekir. Bizim ve bizim gibi birçok sporcunun en büyük eksikliği özel yapım spor sandalyeye erişememektir. Sebebi ise; şuan bir spor sandalyesi yaklaşık 45.000 Türk Lirasıdır. Ülkemizin şartlarını düşündüğ̈̈müzde ne kadar yüksek bir meblağ olduğunu anlyyorsunuzdur..." (Remzi, yaş 28)

\section{Şekil 11}

Kurumsal Destek Şart!

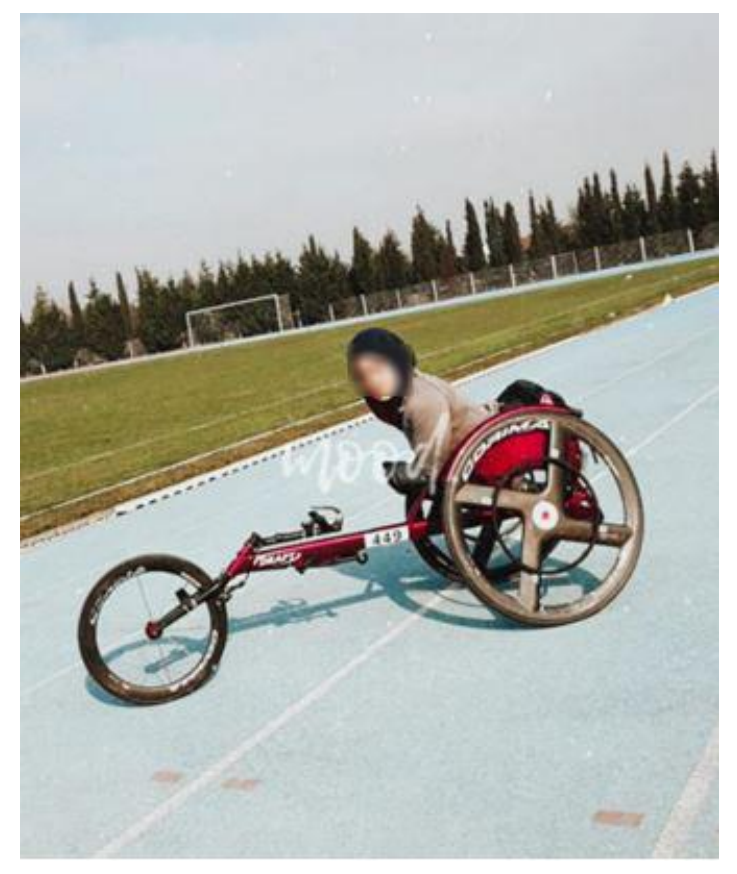

“Yarış sandalyelerimiz yurt dışından kişiye özel üretiliyor ve gerçekten pahalı buna bir araba parası diyebiliriz böyle olunca kendi imkânlarınla almak çok zor ancak bakanlık ya da sponsor yardımıyla alınabilir bu sebeple tekerlekli sandalye atletizm branşı yapan çok sporcu yok." (Zehra, yaş 25)

\section{Şekil 12}

Deplasmanın Olmazsa Olmazı

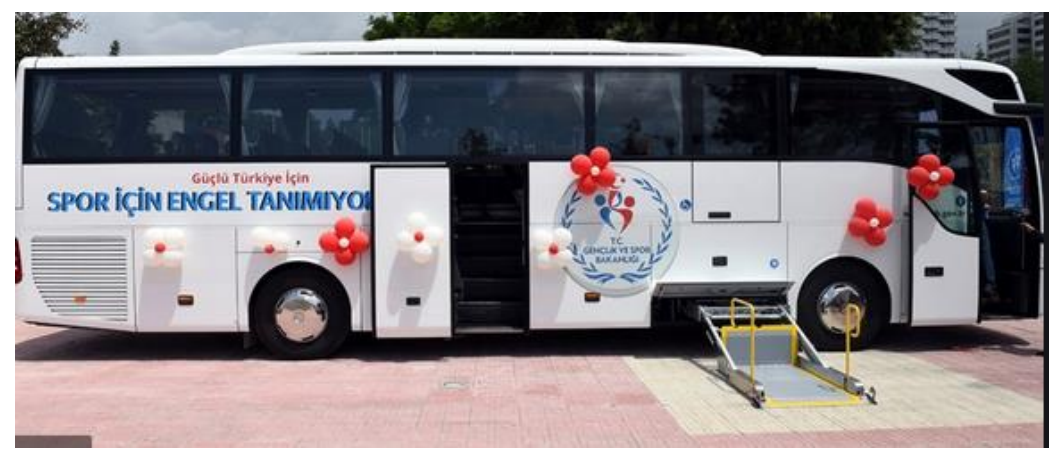

“Sporuma katılımdan önemli engelleyici unsur olarak gördüğ̈̈m başka bir konu ise ulaşımın düzenlenmesi. Bir takım için, sadece bizim branş için değil, tüm takım sporları için söylüyorum bunu deplasman en önemli ve en meşakkatli iştir. Deplasmana ĕger maddi imkânımız yoksa uçakla değil de otobüs yolculuğu yaparak gidiyoruz. Bu bizim vazgeçilmezimiz. Biz engelli bireyler olduğumuz için herkesin rahat bir şekilde inip çıkmasını, yerine oturmasını bekleyemezsiniz. Bunun 
için Gençlik ve Spor Bakanlı̆̆g 20 büyükşehire engellilerin kullanabileceği otobüsler tahsis etti ancak kullanamayanlar da var. Otobüs kiralayıp gittiğimizde merdivenleri de yerde sürünerek çıkan birçok insan, ya da şoförün veya varsa refakatçi insanların yardımıyla kucaktan kucă̆a inip binenler... Bir takım için olmazsa olmaz şey takım otobüsüdür... Ya olmayanlar?" (Remzi, yaş 28)

Bedensel engelli sporcuların görüşleri incelendiğinde kurumsal engelleri daha çok spor alanındaki ihtiyaçlarının bireysel olarak tek tek değil de sürdürülebilir gerçekçi çözümlerle giderilmesi ile özdeşleştirdikleri görülmektedir.

Politik Engeller: Spor Kapsayıcı mı Dışlayıcı mı?: Araştırmamızda bedensel engelli sporcuların spora katılımda karşılaştıkları engelleyici diğer bir faktörde mevcut politikalardan kaynaklı engellerdir. Araştırmada katılımcıların en az fotoğraf çektiği/seçtiği faktör politik engeller olarak belirlenmiştir. Bu tema kapsamında eğitim eksikliği, medya etkisi ve beklentinin karşılanmaması kodları oluşturulmuştur. Bedensel engelli sporcular, ülkemizin pek çok politika belgesi ile engellilerin haklarını garanti altına alındığını ancak sosyal alanlarda yapılamayan ya da görmezden gelinen düzenlemelerin kendilerini engellediğini ve beklentilerini karşılamadığını düşünmektedirler. Özellikle büyükşehirlerde toplu taşımanın normal gelişim gösteren bireyler için bile zorlayıcı bir faktör olduğu düşünülürse, engelliler için çeşitli politikaların üretilmesi gerektiği belirtilmiştir. Bu konuda Ahmet (yaş, 42) seçtiği fotoğrafa ilişkin görüşünü şu şekilde ifade etmiştir.

Şekil 13

Beklemekten Başka Çare Yok!

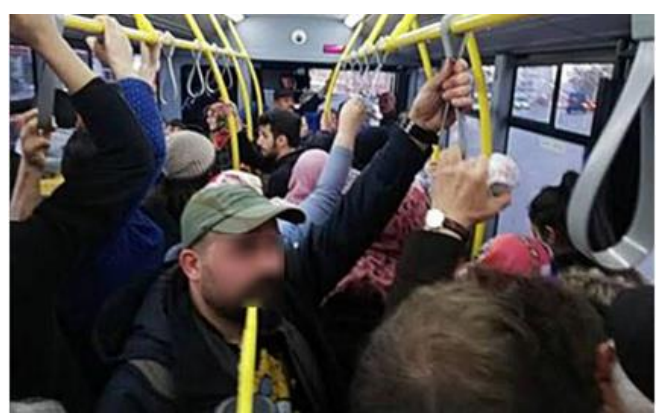

“Özellikle İstanbul'da toplu taşıma araçlarına bir engelli bireyin binmesi kadar zor bir durum olamaz. Çoğu yolculuğumu ayakta yaptım bu yüzden yoğun olmayan saatleri beklemek zorundayım.” (Ahmet, yaş 42)

Bedensel engelli sporcular, spor ortamında oldukça önemli başarılar elde edildiğini ancak medyada kendilerine yeterince yer bulamadıklarını ifade etmektedirler. Ayrıca toplumun engelli bireylere bakış açılarını değiştirecek, onları engellilere nasıl davranmaları gerektiği konusunda eğitecek programlara ihtiyaç olduğunu düşünmektedirler. Bu konuda politikaların hayata geçirilmesi gerektiğini ifade etmektedirler. Bedensel sporcular görüşlerini şu şekilde açıklamışlardır:

Şekil 14

Medyada Bizi Bulabilir Misiniz?

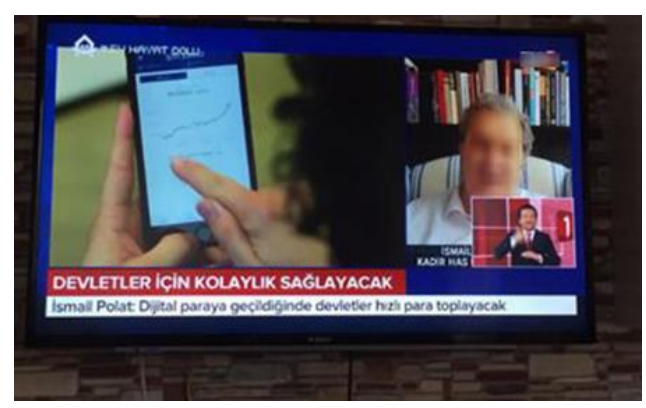


“Bize ilişkin bir program bile yok mesela televizyon programlarında engelliler ve engelli sporcular için daha fazla program yapılmalı. Spor yapmak isteyen engellilere teşvik ettirici ve yönlendirici programlar yapılmalı. Böylelikle devlet politikasıyla daha fazla kitlelere ulaşılır ve spor yapmak isteyen engelliler yönlendirilmiş olur.” (Hasan, yaş 33)

“Engelli olmak beni üzmedi ve kısa bir zaman sonra çok şükür atlattım. Bize bakarak üzülen kişiler veya acıyarak bakanların engelli olunca hayat bitiyor diye düşünmeleri benim gibi engelli olan tüm arkadaşlarımı ve ailelerini üzüyor. Nelere şahit olduk sözlerle, bakışlarla inanın bizi bu durum daha çok üzüyor. Benim isteğim bizi farklı görmemeleri, görmezden gelmeleri ve sosyal medya ve televizyonlarda biraz daha bu konu ile ilgili bilgilendirme yapmalarıdır.” (Ziya, yaş 26)

Bedensel engelli sporcuların görüşlerine göre, ilgili politikaların başarılı bir şekilde uygulanması, bedensel engelli bireylerin karşılaştığı spor katılımı üzerindeki engellerin olumsuz etkisini hafifletmeye yardımcı olabilir.

\section{TARTIŞMA}

Bedensel engelli sporcuların spora katılımlarında karşılaştıkları engellere yönelik deneyimlerini ve bu engelleyici unsurların bireylerin spora katılımlarını nasıl etkilediğini SEM perspektifinden anlamaya çalışması bakımından araştırmanın literatüre önemli katkılar sağlayacağı düşünülmektedir. Literatür incelendiğinde, ülkemizde daha önce fotoses yöntemi ile bu tür bir araştırmanın tasarlanmamış olması, bu araştırmanın yapılması sağlamıştır. Analizler sonucunda bedensel engelli spocuların spor deneyimlerini etkileyen kişisel, sosyal, çevresel, kurumsal ve politik engeller belirlenmiştir.

Bedensel engelli bireylerin toplumdaki diğer bireylere göre daha fazla engelle karşılaştığı bilinen bir gerçektir (King ve diğ., 2003). Bedensel engelli bireyler, yetersiz politikalar, olumsuz tutumlar, hizmet sunumunun yetersizliği, yetersiz finansman, teknolojilere uygun olmayan erişim, bilgi için kapsayıcı formatların olmaması ve sosyal hayatlarını doğrudan etkileyen kararlara katılım eksikliği nedeniyle tüm vatandaşlık alanlarında engellerle karşılaşmaktadırlar (World Health Organization, 2013). Ancak bu engellerin kapsamları toplumdan topluma değişiklik göstermektedir. Aşağıda ülkemizdeki bedensel engelli sporcuların karşılaştıkları engeller literatüre göre tartışılacaktır.

Kişisel Engeller: Diğerleri Gibi Ama Diğerlerinden Farklı: Kişisel engeller teması kapsamında bedensel engelli bireyin engellilik derecesi, uyum sağlamada güçlük, enerji ve motivasyon eksikliği, maddi durum, bilgi eksikliği kodlarına ulaşılmıştır. Araştırmada sporcular kendilerini en çok engelleyen durumların fotoğraflarını seçmişlerdir. Ancak kişisel engele ilişkin seçilen fotoğraf sayısı, diğer engelleyici faktörlere göre daha az sayıda olmuştur. Bu durum bedensel engelli sporcuların fiziksel engellerini aşabildiklerini, spora katılımda kişisel engellerden daha fazla önemsedikleri engellerinin olduğunu göstermektedir. Kişisel engellerle ilgili daha çok engelinin ciddiyeti ve yaptıkları spora uyum sağlama sürecinde engellerle karşılaştıkları görülmektedir. Ancak Freudenberg ve Arlinghaus (2010), Almanya'daki bir kulüpte bedensel engelli ve engeli olmayan bireyleri karşılaştırdığı çalışmasında kişisel faktörleri önemli bir engelleyici unsur olarak rapor etmişlerdir. Yine literatür incelendiğinde bedensel engelli sporcularda en sık bahsedilen kişisel engelin başkalarına bağımlılık olduğu görülmektedir (Jaarsma ve diğ., 2014b).

Sosyal Engeller: Görünür Olma Çabası ve Görünmezlik Algısı: Bu tema kapsamında görünmezlik algısı, yarım insan, bakışların getirdiği zorluk, negatif damgalama, bilgi eksikliği ve prososyal davranış engelleri kodları oluşturulmuştur. Araştırmada katılımcıların en fazla fotoğraf çektiği/seçtiği ikinci önemli faktör sosyal engellerdir. Bedensel engelli sporcular spor ortamında yaşam kalitelerinin arttığını ve kendilerini daha iyi hissettiklerini belirtmişlerdir. Her geçen gün toplumsal sistemlerin işlev ve yapılarının değişime uğraması sonucu yaşam bireyler için daha karmaşık bir hale gelmektedir. Bu durumdan özel gereksinimleri olan bireyler daha fazla etkilenmektedir. Ortaya çıkan bireysel talepler ile toplumsal kaynaklar arasındaki dengesizlik durumunun bedensel engelli sporcular tarafindan 
oldukça fazla algılandığı görülmektedir. Toplumdaki bireylere eşit firsatlar sunmak açısından engelli bireylerin spora katılma firsatlarını anlamak ve deneyimlerini incelemek hayati önem taşımaktadır (Misener ve Darcy, 2014). Ancak toplumdaki bireylerin onları yok saymalarından dolayı özellikle antrenman ortamlarına ulaşmada çok fazla engelle karşılaştıklarını belirtmektedirler. Benzer olarak Crawford ve Stodolska (2008) tarafindan Kenyalı paralimpik sporcular üzerinde yapılan çalışmada da engellilere yönelik tutumlar katılımcılar tarafından en fazla belirtilen engellerden birisi olarak ortaya çıkmaktadır. Gürkan ve Koçak (2020) tarafindan yapılan çalışmada da engelli bireylerin fiziksel aktivitiye katılırken en çok kişiler arası faktörlerden etkilendikleri belirtilmiş̧ir. Engelliler, toplumlarda farklı derecelerde ayrımcılık, dışlanma ve damgalanma yaşayabilmektedir (Smith ve Sparkes, 2012). Gündelik yaşam içinde toplumdaki bireylerin engelli bireylere davranış şekilleri katılımcıların spor hayatlarını da doğrudan etkilemektedir.

Ayrıca bu tema kapsamında önemli görülen bir diğer durum da prososyal davranış engelleridir. Bedensel engelli sporculara çok fazla soru sormak, yardım etmeye çalışırken onları daha zor durumlara düşürmek prososyal davranış engellerine örnek olarak verilebilir. Toplum tarafından dışlanan, kabul görmedikleri hisseden engelli sporcular daha çok olumsuz etkilenerek günlük yaşamlarında bile toplum ile kaynaşmayıp kendilerini soyutladıklarını belirtmişlerdir. Bu durum sosyal engellerin azaltılması ya da ortadan kalkması durumunda engelli bireylerin daha fazla spor ortamı içerisinde olabileceklerini göstermektedir.

Çevresel Engeller: Tek Beden (Yapı) Herkese Uymaz: Bedensel engelli sporcuların spora katılımındaki diğer önemli faktör ise çevresel engellerdir. Çevresel faktörlerler bedensel engelli bireylerin spora katılımında oldukça önemli bir faktör olarak görülmektedir. Araştırmamızda ulaşım güçlükleri, erişim engelleri (örneğin; rampa eğimi, kaldırımlar vb.), güvensiz ortamlar, hava koşulları, tasarım eksiklikleri kodları oluşturulmuştur. Literatür incelendiğinde de engelli bireylerin spora katılımında ulaşım eksikliği ve fiziksel engeli olmayan bireylerden destek alınmaması önemli bir engel olarak görülmektedir (Jaarsma ve diğ., 2014a). Araştırmamızda seçilen/çekilen fotoğraflar incelendiğinde en fazla engelin çevresel engeller olduğu dikkat çekmektedir. Literatürde olanaksızlık, erişilmezlik ve ulaşım gibi çevresel engellerin, fiziksel engelleri olan kişiler tarafindan özel olarak deneyimlenen ek engeller olduğu belirtilmektedir (Jaarsma ve diğ., 2014a). Bedensel engelli sporcular spor salonlarının ve diğer kamusal alanların normal gelişim gösteren bireylere göre düzenlendiğini ancak, engellilere yönelik son dönemlerde düzenlemeler yapılsa da yine çok fazla eksikliğin olduğu belirtilmiştir. Özellikle kaldırımların yüksekliği, kaldırımlara park eden arabaların varlığı ve engelliler için yapılmış olsa bile engelli rampalarının engellerin kullanımına uygun olmaması araştırmaya katılan bedensel engelli sporcuların ortak sorunu olarak ortaya çıkmaktadır. Gürbüz ve Henderson (2014) da fiziksel aktiviteye katılım için tesislere ulaşımın bireyler açısından oldukça önemli olduğunu vurgulamışlardır. Literatürde ayrıca spor olanaklarının eksikliği (Stroud ve diğ., 2009), erişilebilirlikle ilgili zorluklar (Tasiemski ve diğ., 2004) ve ulaşım (Mojtahedi ve Katsui, 2018) bedensel engelli yetişkinler tarafindan spora katılımdaki engeller olarak rapor edilmiştir.

Sporculara göre bedensel engelli bireylerin önlerindeki kişisel ve sosyal engellerin tümünü ortadan kaldırsak bile çevresel engellerin varlığı spora katılım oranlarını oldukça düşürmektedir. Bu duruma bir de toplumdaki diğer bireylerin davranışları eklendiğinde çevrenin onlar için güvenli olmadığını düşünmektedirler. Araştırmaya katılan sporcular tekerlekli sandalye kullandıkları için özellikle çevresel engellerde hava koşullarına dikkat çekmişlerdir. Yağışlı ya da karlı havaların tüm bireyler için zorluklarının olduğunu ancak, bedensel engelli sporcular için daha önemli olduğunu belirtmişlerdir. Sporcuların görüşlerine göre çevresel engellerin varlığı spora katılımı doğrudan etkilemektedir. Ancak çevresel engellerin pek çoğu (hava koşulları dışında) onlara göre bedensel engelli bireyleri göz ardı etmekten ve engelli bireyler hakkında yeterince bilgi sahibi olmamaktan kaynaklanmaktadır. Bu nedenle sosyal engelleri aştıklarında çevresel engelleri de aşabileceklerini düşünmektedirler. 
Kurumsal Engeller: Kalıcı Çözümler için Geride Kalanlar: Bedensel engelli sporcuların spora katılımda karşılaştıkları diğer önemli faktör ise kurumsal engellerdir. Kurumsal faktörlerde bedensel engelli sporcuların spor yaptıkları kurumlar ya da ortamlarla ilgili karşılaştıkları engeller ortaya koyulmaya çalışılmıştır. Araştırmada katılımcıların en az fotoğraf çektiği/seçtiği ikinci önemli faktör kurumsal engeller olarak belirlenmiştir. Bu tema kapsamında sürdürülebilirlik eksikliği, sistematik yaklaşım eksikliği ve bağımsızlık temelli ulaşım planlamasının yetersizliği kodları oluşturulmuştur. Bu faktörde bedensel engelli sporcular nitelikli spor ekipmanlarına kurumsal yapıda sistematik olarak ulaşamadıklarını belirtmektedirler. Literatür incelendiğinde de spor ekipmanlarının yüksek maliyetleri engellilerin spora katılımında önemli bir engel olarak görülmektedir (Murphy ve Carbone, 2008).

Ayrıca bedensel engelli sporcular tarafından ifade edilen bir diğer kurumsal engel ise, iyi gelişmeler yaşansa da ulaşım sorunun tüm engelli sporcular ve kulüpler için ilgili kurumlar tarafından sürdürülebilir olarak çözülememesidir. Dwyer ve diğerleri (2008) de çalışmalarında bu durumu vurgulayarak kamu kaynaklarının artırılmasının engelli bireylerin fiziksel aktiviteye katılımını teşvik etme anlamında önemli bir faktör olduğunu belirtmektedir.

Bedensel engelli sporcuların görüşleri incelendiğinde, sporcuların kurumsal engelleri daha çok spor alanındaki ihtiyaçlarının bireysel olarak tek tek değil de sürdürülebilir gerçekçi çözümlerle giderilmesi ile özdeşleştirdikleri görülmektedir.

Politik Engeller: Spor Kapsayıcı mı Dışlayıcı mı?: Araştırmamızda bedensel engelli sporcuların spora katılımda karşılaştıkları diğer önemli faktör ise mevcut politikalardan kaynaklı engellerdir. Araştırmada en az fotoğraf çektiği/seçtiği faktör politik engeller olarak belirlenmiştir. Bu tema kapsamında eğitim eksikliği, medya etkisi ve beklentinin karşılanmaması kodları oluşturulmuştur. Bedensel engelli sporcular ülkemizde pek çok politika belgesi ile engellilerin haklarını garanti altına aldığını ancak sosyal alanlarda yapılamayan ya da görmezden gelinen düzenlemelerin kendilerini engellediğini ve beklentilerini karşılamadığını düşünmektedirler. Özellikle büyükşehirlerde toplu taşımanın normal gelişim gösteren bireyler için bile zorlayıcı bir faktör olduğu düşünülürse, engelliler için çeşitli politikaların üretilmesi gerektiği belirtilmiştir.

Bedensel engelli sporcular, spor ortamında oldukça önemli başarılar elde edildiğini ancak medyada kendilerine yeterince yer bulamadıklarını ifade etmektedirler. Ayrıca toplumun engelli bireylere bakış açılarını değiştirecek, onları engellilere nasıl davranmaları gerektiği konusunda eğitecek programlara ihtiyaç olduğunu düşünmektedirler. Bu konuda politika tedbirlerinin hayata geçirilmesi gerektiğini ifade etmektedirler. Benzer olarak Wilson ve Khoo (2013) da Malezyalı engelli sporcuların karşı karşıya kaldığı engellerin çoğunlukla yapısal (tesisler, ekipman, finansman) olmakla birlikte, sporcuların hükümetten, kamuoyundan ve medyadan hissettikleri olumsuz tutumun da oldukça önemli bir yere sahip olduğunu belirtmişlerdir.

Bedensel engelli sporcuların görüşlerine göre, ilgili politikaların başarılı bir şekilde uygulanması, bedensel engelli bireylerin karşılaştığı spor katılımı üzerindeki engellerin olumsuz etkisini hafifletmeye yardımcı olabilir.

\section{SONUÇ}

Sonuç olarak bedensel engelli sporcuların spora katılımda çeşitli engellerle karşılaştıkları görülmektedir. Karşılaşılan bu engeller günlük hayatlarını etkilediği gibi spor hayatlarını da olumsuz etkilemektedir. Ancak spor, engelli bireylerin kendilerini ifade edebildikleri, hatta engellerini aşabildikleri bir olgu olarak görülmektedir. Araştırmamızdan elde edilen sonuçlar, sporcuların erişim ihtiyaçlarını ele almaya odaklanmamız gerektiğini bize hatırlatmaktadır. Bedensel engelli sporculara göre sosyal engeller ve çevresel engeller çözülmesi en zor konulardan biri olarak düşünülmektedir. Araştırmada fotoses yönteminin tercih edilmesinin soyut olarak algılanan engellerin somutlaştırılmasına katkı sağladığ düşünülmektedir. Bedensel engelli sporcuların bakış açıları ve deneyimlerinden yararlanmak, politika yapıcılar için 
benzer durumdaki bireylerin karşılaştığı durumlara yönelik kalıcı çözümler üretmek için temel bir hareket noktası olabilir. $\mathrm{Bu}$ engellerin ortadan kaldırılması veya azaltılması durumunda engelli sporlarının daha fazla gelişim göstereceği düşünülmektedir. Gelecekte yapılacak çalışmalarda ise farklı yaş gruplarına yönelik araştırmalar tasarlanabilir. Benzer bir araştırma farklı engel gruplarına yönelik olarak yapılabilir. Ayrıca bedensel engelli sporcuların spora katılımlarında engelleyici faktörlerin yanı sıra baş etme stratejileri, kolaylaştırıcılar ve spora katılım motivasyonları ile ilgili çalışmalar da planlanabilir.

\section{Yazar Katkısı:}

1. Metin ARGAN: Fikir/Kavram, Tasarım, Denetleme, Analiz-Yorum, Makale Yazımı, Eleştirel İnceleme

2. Bülent GÜRBÜZ: Fikir/Kavram, Tasarım, Veri Toplama ve/veya İşleme, Analiz-Yorum, Eleştirel İnceleme

3. Funda KOÇAK: Tasarım, Veri Toplama ve/veya İşleme, Analiz-Yorum, Makale Yazımı

4. Merve ATICI: Veri Toplama ve/veya İşleme, Makale Yazımı

\section{Etik Kurul İzni ile İlgili Bilgiler}

Kurul Adı: Eskişehir Teknik Üniversitesi Sosyal ve Beşeri Bilimler Bilimsel Araştırma Yayın Etiği Kurulu

Tarih: 31.03 .2020

Sayı No: 87914409-050.99 


\section{KAYNAKÇA}

1. Albrecht, J., Elmose-Østerlund, K., Klenk, C., ve Nagel, S. (2019). Sports clubs as a medium for integrating people with disabilities. European Journal for Sport and Society, 16(2), 88-110. https://doi.org/10.1080/16138171.2019.1607468

2. Argan, M., Yılmaz, A., Argan, M.T., ve Yetim, G. (2020). Sesimi gören var mı? Fotoses yönteminin spor bilimlerinde kullanım potansiyeline ilişkin kuramsal bir çerçeve. Gazi Beden Eğitimi ve Spor Bilimleri Dergisi, 25(3), 149-166.

3. Bronfenbrenner, U. (1979). The ecology of human development: experiments by nature and design. Cambridge, MA: Harvard University Press.

4. Burns, R.C., ve Graefe, A.R. (2007). Constraints to outdoor recreation: Exploring the effects of disabilities on perceptions and participation. Journal of Leisure Research, 39(1), 156-181. https://doi.org/10.1080/00222216.2007.11950102

5. Burns, J. (2021). Inclusion and exclusion of elite athletes with disabilities. In D. Chatziefstathiou (Ed.) Routledge handbook of the olympic and paralympic games. Newyork, NY: Routledge.

6. Chatfield, S.L., ve Cottingham II, M. (2017). Perceptions of Athletes in disabled and non-disabled sport contexts: A descriptive qualitative research study. The Qualitative Report, 22(7), 1909-1924. https://doi.org/10.46743/2160-3715/2017.2483

7. Çokluk, Ö., Yılmaz, K., ve Oğuz, E. (2011). Nitel bir görüşme yöntemi: Odak grup görüşmesi. Kuramsal Ĕ̆itimbilim Dergisi, 4 (1), 95-107.

8. Creswell, J.W. (2018). Nitel araştırma yöntemleri: Beş yaklaşıma göre nitel araştırma ve araştırma desenleri. ( M. Bütün ve S.B. Demir, Çev.). Ankara: Siyasal Kitabevi. (orjinal yayınlanma, 2012)

9. Cottingham II, M., Carroll, M., Lee, D., Shapiro, D., ve Pitts, B. (2016). The historical realization of the Americans with disabilities act on athletes with disabilities. Journal of Legal Aspects of Sport, 26, 5-21. http://dx.doi.org/10.1123/ilas.2015-0014

10. Crawford, J.L., ve Stodolska, M. (2008). Constraints experienced by elite athletes with disabilities in Kenya, with implications for the development of a new hierarchical model of constraints at the societal level. Journal of Leisure Research, 40(1), 128-155. https://doi.org/10.1080/00222216.2008.11950136

11. Darcy, S., Lock, D., ve Taylor, T. (2017). Enabling inclusive sport participation: Effects of disability and support needs on constraints to sport participation. Leisure Sciences, 39(1), 20-41. https://doi.org/10.1080/01490400.2016.1151842

12. DePauw, K.P., ve Gavron, S.J. (2005). Disability sport(2nd ed.). Champaign, IL: Human Kinetics.

13. Driver, B.L., Brown, P.J., ve Peterson, G.L. (1991). Benefits of leisure. State College; IL: Champaign, Venture Publishing.

14. Dwyer, J., Needham, L., Simpson, J.R,. ve Heeney, E.S. (2008). Parents report intrapersonal, interpersonal, and environmental barriers to supporting healthy eating and physical activity among their preschoolers. Applied Physiology, Nutrition, and Metabolism, 33(2), 338-346. https://doi.org/10.1139/H07-195

15. Engelliler Hakkında Kanun 2005. https://www.resmigazete.gov.tr/eskiler/2005/07/20050707-2.htm

16. Engellilerin Haklarına İlişkin Sözleşme 2009. https://www.resmigazete.gov.tr/eskiler/2009/07/20090714-1.htm

17. Esatbeyoğlu, F., ve Karahan, B.G. (2014). Engelli bireylerin fiziksel aktiviteye katılımlarının önündeki engeller. Spor Bilimleri Dergisi, 25(2), $43-55$.

18. Erdugan, F.E. (2010). Türkiye'de özürlü yoksulluğu ve mücadele politikalarının değerlendirilmesi: Ankara-Keçiören örneği. Ankara: TC Başbakanlık Özürlüler İdaresi Başkanlığı Yayınları

19. Fleury, J., ve Lee, S.M. (2006). The social ecological model and physical activity in African American women. American journal of community psychology, 37(1-2), 129-140. https://doi.org/10.1007/s10464-005-9002-7

20. Freudenberg, P., ve Arlinghaus, R. (2010). Benefits and constraints of outdoor recreation for people withphysical disabilities: Inferences from recreational fishing. Leisure Sciences, 32 (1), 55-71. https://doi.org/10.1080/01490400903430889

21. Gençlik ve Spor Bakanlığı (2019). Stratejik plan 2019-2023. https://gsb.gov.tr/public/edit/files/strateji/2019-2023-StratejikPlan\%C4\%B1.pdf

22. Ghimire, R., Green, G.T., Poudyal, N.C., ve Cordell, H.K. (2014). An analysis of perceived constraints to outdoor recreation. Journal of Park and Recreation Administration, 32(4), 52-67.

23. Grenier, M., ve Kearns, C. (2012). The benefits of implementing disability sports in physical education: A model for success. Journal of Physical Education, Recreation \& Dance, 83(4), 23-27. https://doi.org/10.1080/07303084.2012.10598758

24. Gürbüz, B., ve Henderson, K.A. (2014). Leisure activity preferences and constraints: Perspectives from Turkey. World Leisure Journal, 56(4), 300-316. https://doi.org/10.1080/16078055.2014.958195

25. Gurkan, R.K., ve Kocak, F. (2020). Perceived constraints and facilitators of participation in physical activity by individuals with autism spectrum disorders. Physical Activity Review, 8(1), 51-63. https://doi.org/10.16926/par.2020.08.07

26. Haegele, J.A., ve Hodge, S. (2016). Disability discourse: Overview and critiques of the medical and social models. Quest, 68(2), 193-206. https://doi.org/10.1080/00336297.2016.1143849

http://www.sbd.hacettepe.edu.tr 
27. Hammond, A., ve Jeanes, R. (2018). Federal government involvement in Australian disability sport, 1981-2015. The International Journal of the History of Sport, 35(5), 431-447. https://doi.org/10.1080/09523367.2017.1337000

28. Haslett, D., Choi, L., ve Smith, B. (2020). Para athlete activism: A qualitative examination of disability activism through Paralympic sport in Ireland. Psychology of Sport and Exercise, 47, 101639, 1-9. https://doi.org/10.1016/j.psychsport.2019.101639

29. Hoekstra, F., Roberts, L., van Lindert, C., Martin Ginis, K.A., van der Woude, L.H., ve McColl, M.A. (2019). National approaches to promote sports and physical activity in adults with disabilities: examples from the Netherlands and Canada. Disability and rehabilitation, 41(10), 1217-1226. https://doi.org/10.1080/09638288.2017.1423402

30. Hutzler, Y., Chacham-Guber, A., ve Reiter, S. (2013). Psychosocial effects of reverse-integrated basketball activity compared to separate and no physical activity in young people with physical disability. Research in Developmental Disabilities, 34(1), 579-587. https://doi.org/10.1016/j.ridd.2012.09.010

31. Ives, B., Clayton, B., Brittain, I., ve Mackintosh, C. (2019). 'I'll always find a perfectly justified reason for not doing it': challenges for disability sport and physical activity in the United Kingdom. Sport in Society, 24(4), 1-19. https://doi.org/10.1080/17430437.2019.1703683

32. Jaarsma, E.A., Dijkstra, P.U., Geertzen, J.H.B., ve Dekker, R. (2014a). Barriers to and facilitators of sports participation for people with physical disabilities: A systematic review. Scandinavian Journal of Medicine \& Science in Sports, 24(6), 871-881. https://doi.org/10.1111/sms.12218

33. Jaarsma, E.A., Geertzen, J.H., Jong, R., Dijkstra, P.U., ve Dekker, R. (2014b). Barriers and facilitators of sports in Dutch Paralympic athletes: An explorative study. Scandinavian Journal of Medicine \& Science in Sports, 24(5), 830-836. https://doi.org/10.1111/sms.12071

34. Kang, M., Zhu, W., Ragan, B.G., ve Frogley, M. (2007). Exercise barrier severity and perseverance of active youth with physical disabilities. Rehabilitation Psychology, 52(2), 170-176. https://doi.org/10.1037/0090-5550.52.2.170

35. King, G., Lawm, M., King, S., Rosenbaum, P., Kertoy, M.K., ve Young, N.L. (2003). A conceptual model of the factors affecting the recreation and leisure participation of children with disabilities. Physical \& occupational therapy in pediatrics, 23(1), 63-90. https://doi.org/10.1080/J006v23n01_05

36. Liu, Y.D. (2009). Sport and social inclusion: Evidence from the performance of public leisure facilities. Social indicators research, 90(2), 325337. https://doi.org/10.1007/s11205-008-9261-4

37. Lincoln, Y.S., ve Guba, E.G. (1986). But is it rigorous? Trustworthiness and authenticity in naturalistic evaluation. New directions for program evaluation, 30, 73-84. https://doi.org/10.1002/ev.1427

38. Lyu, S.O., ve Lee, H. (2016). Latent demand for recreation participation and leisure constraints negotiation process: Evidence from Korean people with disabilities. Journal of Leisure Research, 48(5), 431-449. https://doi.org/10.18666/JLR-2016-V48-I5-6511

39. Malterud, K. (2016). Theory and interpretation in qualitative studies from general practice: why and how?. Scandinavian Journal of Public Health, 44(2), 120-129. https://doi.org/10.1177/1403494815621181

40. Martin, JJ.. (2013). Benefits and barriers to physical activity for individuals with disabilities: a social-relational model of disability perspective. Disability and Rehabilitation, 35(24), 2030-2037. https://doi.org/10.3109/09638288.2013.802377

41. McLeroy, K.R., Bibeau, D., Steckler, A., ve Glanz, K. (1988). An ecological perspective on health promotion programs. Health Education Quarterly, 15(4), 351-377. https://doi.org/10.1177/109019818801500401

42. McLoughlin, G., Fecske, C.W., Castaneda, Y., Gwin, C., ve Graber, K. (2017). Sport participation for elite athletes with physical disabilities: Motivations, barriers, and facilitators. Adapted Physical Activity Quarterly, 34(4), 421-441. https://doi.org/10.1123/apaq.2016-0127

43. Misener, L., ve Darcy, S. (2014). Managing disability sport: From athletes with disabilities to inclusive organisational perspectives. Sport Management Review, 17 (1), 1-7. https://doi.org/10.1016/j.smr.2013.12.003

44. Mobily, K.E., ve Dieser, R.B. (2018). Seeking alternatives in therapeutic recreation/recreation therapy: A social/recreation community model. Leisure/Loisir, 42(1), 1-23. https://doi.org/10.1080/14927713.2017.1403860

45. Mojtahedi, M.C., ve Katsui, H. (2018). Making the right real! A case study on the implementation of the right to sport for persons with disabilities in Ethiopia. Sport in Society, 21(1), 40-49. https://doi.org/10.1080/17430437.2016.1225898

46. Murphy, N.A., ve Carbone, P.S. (2008). Promoting the participation of children with disabilities in sports, recreation, and physical activities. Pediatrics, 121(5), 1057-1061. https://doi.org/10.1542/peds.2008-0566

47. Noble, H., ve Smith, J. (2015). Issues of validity and reliability in qualitative research. Evidence-based Nursing, 18(2), 34-35. http://dx.doi.org/10.1136/eb-2015-102054

48. Obrusnikova, I., ve Cavalier, A.R. (2011). Perceived barriers and facilitators of participation in after-school physical activity by children with autism spectrum disorders. Journal of Developmental and Physical Disabilities, 23(3), 195-211. https://doi.org/10.1007/s10882-010-9215-z

49. Oliver, M. (2013). The social model of disability: Thirty years on. Disability \& Society, 28(7), 1024-1026. https://doi.org/10.1080/09687599.2013.818773 
50. Patton, M.Q. (2002). Two decades of developments in qualitative inquiry: A personal, experiential perspective. Qualitative Social Work, 1(3), 261-283. https://doi.org/10.1177/1473325002001003636

51. Richard, R., Burlot, F., Duquesne, V., ve Joncheray, H. (2021). "I had a dream: it was to play the games". Sports socialisation processes of French paralympic athletes.European Journal for Sport and Society, 1-18. https://doi.org/10.1080/16138171.2021.1878438

52. Sarol, H., ve Çimen, Z. (2015). The effects of adapted recreational physical activity on the life quality of individuals with autism. The Anthropologist, 21(3), 522-527. https://doi.org/10.1080/09720073.2015.11891842

53. Singleton, J., ve Darcy, S. (2013). 'Cultural life', disability, inclusion and citizenship: moving beyond leisure in isolation. Annals of Leisure Research, 16(3),183-192. https://doi.org/10.1080/11745398.2013.826124

54. Smith, B., ve Sparkes, A.C. (2012). Disability, sport and physical activity. A critical review. In N. Watson, A. Roulstone, \& C. Thomas (Eds.), Routledge Handbook of Disability Studies, London: Routledge.

55. Smith, R.W., Austin, D.R., ve Kennedy, D.W. (1996). Inclusive and special recreation: Opportunities for persons with disabilities. (3rd Ed.), Dubuque, IA: Brown and Benchmark Publishing.

56. Sotiriadou, P., ve Wicker, P. (2014). Examining the participation patterns of an ageing population with disabilities in Australia. Sport Management Review, 17(1), 35-48. https://doi.org/10.1016/j.smr.2013.04.004

57. Stroud, N., Minahan, C., ve Sabapathy, S. (2009). The perceived benefits and barriers to exercise participation in persons with multiple sclerosis. Disability and Rehabilitation, 31(26), 2216-2222. https://doi.org/10.3109/09638280902980928

58. Tasiemski, T., Kennedy, P., Gardner, B.P., ve Blaikley, R.A. (2004). Athletic identity and sports participation in people with spinal cord injury. Adapted Physical Activity Quarterly, 21(4), 364-378. https://doi.org/10.1123/apaq.21.4.364

59. Türkiye İstatistik Kurumu (2019). Türkiye sağllk araştırması. https://data.tuik.gov.tr/Search/Search?text=engelli\&dil=1

60. Úbeda-Colomer, J., Ginis, K.A.M., Monforte, J., Pérez-Samaniego, V., ve Devís-Devís, J. (2019). Predicting physical activity in university students with disabilities: The role of social ecological barriers in the theory of planned behaviour. Disability and Health Journal, 12(4), 574580. https://doi.org/10.1016/j.dhjo.2019.06.008

61. United Nations (2006) United Nations Convention on the rights of persons with disabilities. http://www.un.org/esa/socdev/enable/rights/convtexte.htm

62. Verdonschot, M.M., De Witte, L.P., Reichrath, E., ve Buntinx, W.H.E., ve Curfs, L.M. (2009). Community participation of people with an intellectual disability: A review of empirical findings. Journal of Intellectual Disability Research, 53(4), 303-318. https://doi.org/10.1111/j.13652788.2008.01144.x

63. Wang, C., ve Burris, M.A. (1994). Empowerment through photo novella: Portraits of participation. Health Education Quarterly, 21(2), 171186. https://doi.org/10.1177/109019819402100204

64. Wang, C, ve Burris, M.A. (1997). Photovoice: Concept, methodology, and use for participatory needs assessment. Health Education \& Behavior, 24(3), 369-387. https://doi.org/10.1177/109019819702400309

65. Wilson, N.C., ve Khoo, S. (2013). Benefits and barriers to sports participation for athletes with disabilities: the case of Malaysia. Disability \& Society, 28(8), 1132-1145. https://doi.org/10.1080/09687599.2012.758034

66. World Health Assembly 66, World Health Organization (2013). Disability: report by the Secretariat. https://apps.who.int/iris/handle/10665/105691

67. World Health Organization, ve World Bank (2011). World report on disability. https://www.who.int/disabilities/world_report/2011/report.pdf 